\title{
Construction Safety Program for the National Ignition Facility
}

\section{Appendix A}

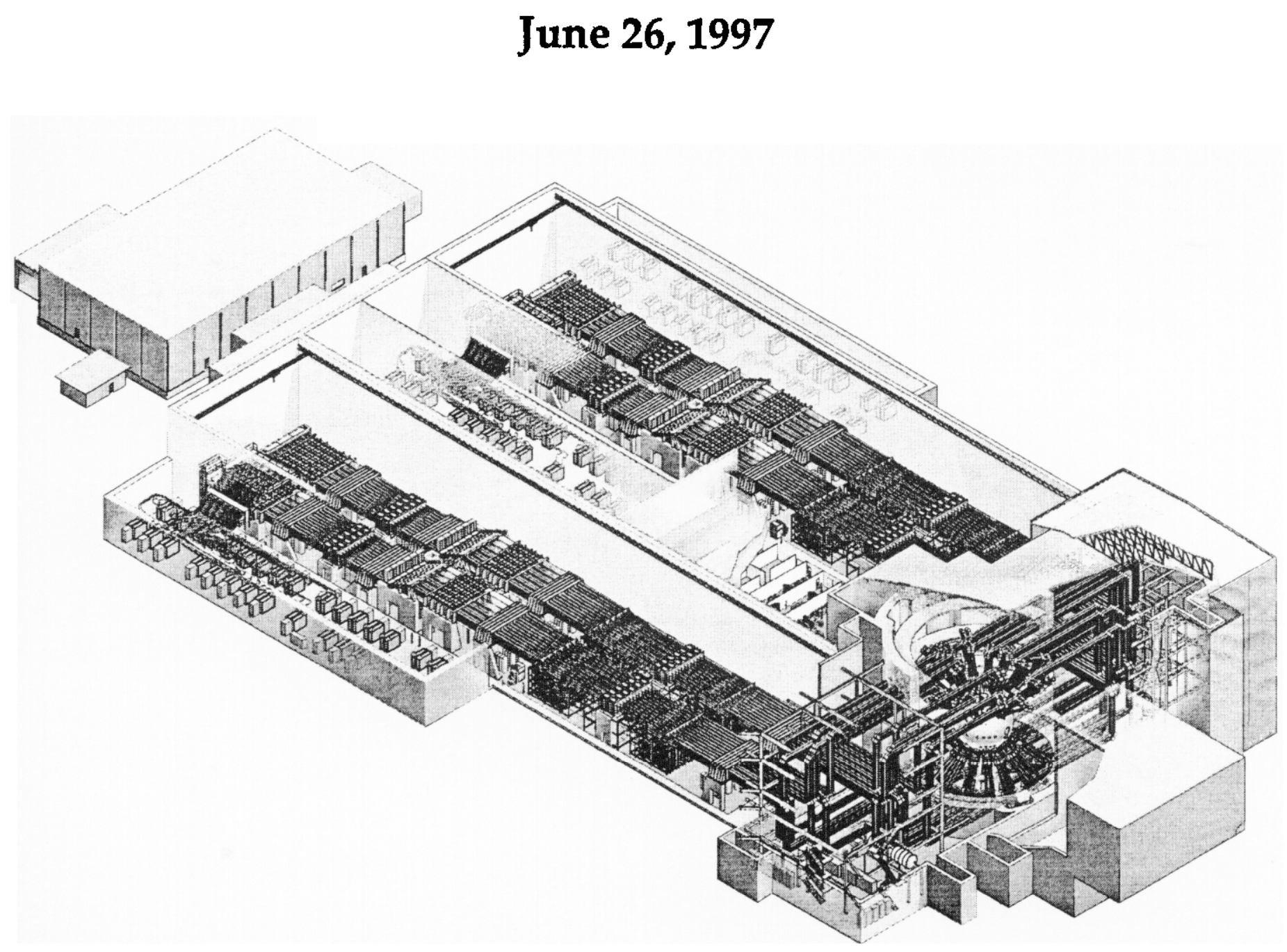




\section{DISCLAIMER}

This document was prepared as an account of work sponsored by an agency of the United States Government. Neither the United States Government nor the University of California nor any of their employees, makes any warranty, express or implied, or assumes any legal liability or responsibility for the accuracy, completeness, or usefulness of any information, apparatus, product, or process

disclosed, or represents that its use would not infringe privately owned rights. Reference herein to any specific commercial product, process, or service by trade name, trademark, manufacturer, or otherwise, does not necessarily constitute or imply its endorsement, recommendation, or favoring by the United States Government or the University of California. The views and opinions of authors expressed herein do not necessarily state or reflect those of the United States Government or the University of California, and shall not be used for advertising or product endorsement purposes. 


\title{
Construction Safety Program for the National Ignition Facility Appendix A
}

\author{
Steven J. Cerruti
}

June 26, 1997 
NIF-0001374

UCRL-ID-125990 Rev. 1 


\section{Contents}

1. General Rules - Code of Safe Practices...............................................................

2. Personal Protective Equipment ............................................................................... A-11

3. Hazardous Material Control....................................................................................14

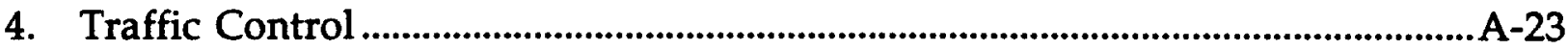

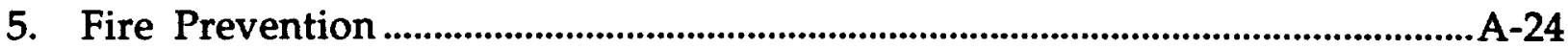

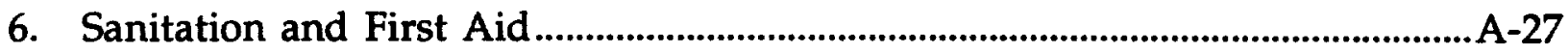

7. Confined Space Safety Requirements........................................................................29

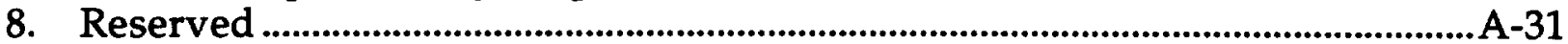

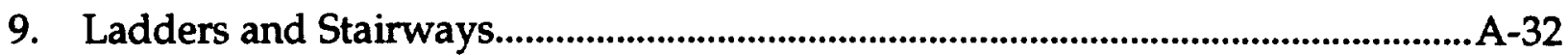

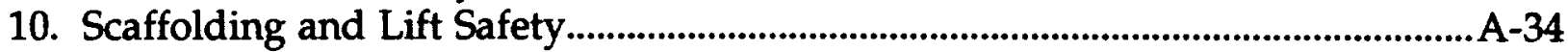

11. Machinery, Vehicles, and Heavy Equipment............................................................-38

12. Welding and Cutting-General ..........................................................................A-41

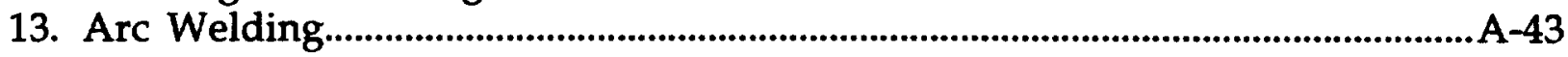

14. Oxygen/Acetylene Welding and Cutting ................................................................A-45

15. Excavation, Trenching, and Shoring..................................................................47

16. Fall Protection...............................................................................................................

17. Steel Erection ....................................................................................................................A-52

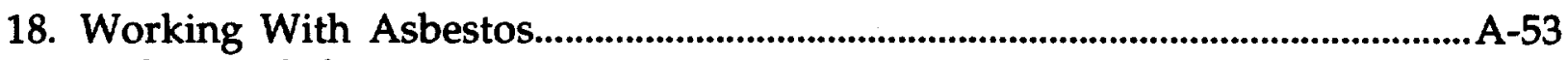

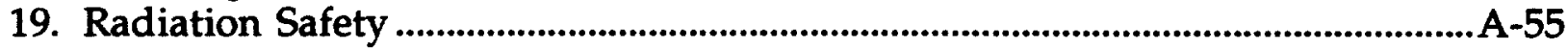

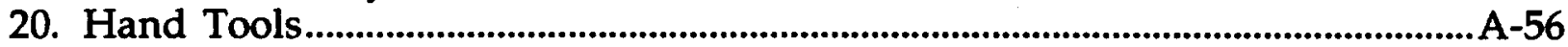

21. Electrical Safety ................................................................................................................. A-58

22. Nonelectrical Work Performed Near Exposed High-Voltage Power-Distribution Equipment .................................................................................... A-61

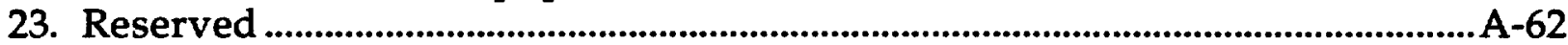

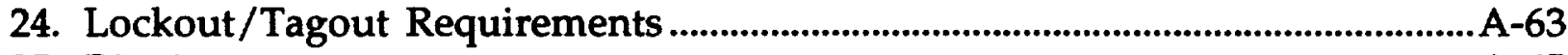

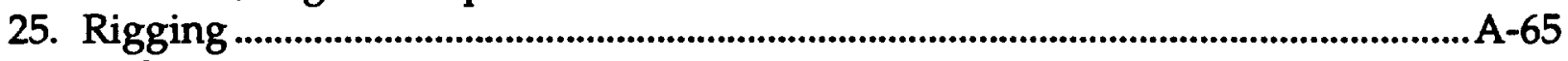

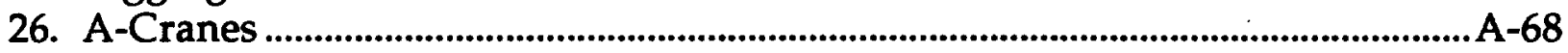

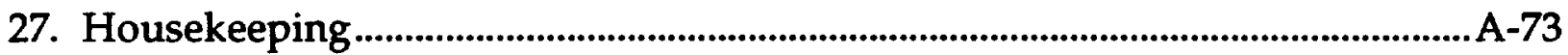

28. Material Handling and Storage.........................................................................

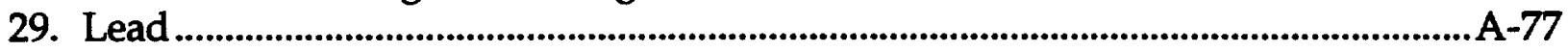

30. Concrete and Masonry Construction...............................................................................A-78 


\section{General Rules-Code of Safe Practices}

These rules apply to all LLNL employees, non-LLNL employees (including contract labor, supplemental labor, vendors, personnel matrixed/assigned from other National Laboratories, participating guests, visitors and students) and construction contractors/subcontractors. The General Rules-Code of Safe Practices shall be used by management to promote accident prevention through indoctrination, safety and health training and on-the-job application.

As a condition for contracts award, all contractors and subcontractors and their employees must certify on Form S \& H A-1 that they have read and understand, or have been briefed and understand, the National Ignition Facility OCIP Project General Rules-Code of Safe Practices. (An interpreter must brief those employees who do not speak or read English fluently.) In addition, all contractors and subcontractors shall adopt a written General Rules-Code of Safe Practices that relates to their operations. The General Rules-Code of Safe Practices must be posted at a conspicuous location at the job site office or be provided to each supervisory employee who shall have it readily available. Copies of the General Rules-Code of Safe Practices can also be included in employee safety pamphlets.

\section{Responsibilities}

NIF Construction Contractors/Subcontractors

1. All Construction Contractors/Subcontractors employees shall comply with the following General Rules-Code of Safe Practices.

University Employees and Non-LLNL employees (reference Section I.A.14 for definition)

1. All LLNL employees and non-LLNL employees (including contract labor, supplemental labor, vendors, personnel matrixed/assigned from other National Laboratories, participating guests, visitors and students) at a minimum shall comply with the LLNL Environment, Safety, and Health Program and applicable requirements of the NIF Construction Safety Program, including the following General Rules-Code of Safe Practices.

\section{Exceptions}

Requests by NIF Construction Contractors/Subcontractors for exceptions/modifications to LLNL safety requirements will only be approved if equivalent safety is demonstrated and OSHA requirements are met. Approvals shall be issued in writing by the cognizant Construction Manager (or Deputy Associate Project Engineer for Construction) with concurrence from LLNL's Safety Representative for the NIF project. 


\section{General Rules-Code of Safe Practices}

\section{General}

1. All employees shall comply with this Code of Safe Practices, assist all other employees in doing so, and report all dangerous conditions or practices immediately to their supervisors.

2. Supervisors shall insist on employees observing and obeying every rule, regulation, and order as is necessary to the safe conduct of the work, and shall take such action as is necessary to obtain observance.

3. Think Safety! If you have and maintain an attitude of safety on the job, then the chances of being injured are very greatly reduced. Report all unsafe or unhealthful practices and conditions to your supervisor at once.

4. All injuries shall be reported promptly to the foreman or supervisor so that arrangements can be made for medical or first aid treatment.

5. When injuries occur, the first step is always to provide medical care for the injured and eliminate immediately any apparent cause of the injury. If a cause is not apparent, the work area and equipment shall be secured until the cause is determined by qualified authorities.

6. All employees shall be given frequent accident prevention instructions. Instructions shall be given at a 5-minute (or more) safety meeting at the beginning of each shift, and at a weekly safety meeting.

7. It is a part of every employee's job to attend and take an active part in all safety training meetings and to actively support the company's safety program. Read and abide by all safety materials made available to you. They concern your safety and health and the safety and health of your fellow workers.

8. No one shall knowingly be permitted to work while his/her ability or alertness is impaired by illness, fatigue, medication, or other causes.

9. Reporting to work under the influence of alcohol, stimulants, tranquilizers, or barbiturates-or using them during working hours-will be cause for arrest and permanent removal from the LLNL work site and grounds for disciplinary or legal action if warranted.

10. Horseplay, scuffling, and other acts which tend to have an adverse influence on the safety or well-being of the employees shall be prohibited.

11. Work shall be well planned and supervised to prevent injuries in the handling of materials and in working together with equipment.

12. Employees shall not handle, or tamper with electrical equipment, machinery, vehicles, or air and water lines in a manner outside of the scope of their regular duty except with specific instructions from their supervisors.

13. Employees shall not enter manholes, underground vaults, chambers, tanks, silos, trenches, ditches, or any other subsurface area, or confined spaces without specific instructions from their supervisors, and it has been determined safe to enter. 
14. Always be as familiar as possible and alert at all times to conditions and work processes in surrounding areas and with the presence of other workers and equipment so that you can foresee and avoid possible dangers.

15. "Roped off areas" or areas enclosed with barricades are considered danger zones and shall be respected as such. Admittance to or passage through such areas is prohibited without permission except to those employees working within the barricaded area.

16. When work requires barricades or floor opening covers to be temporarily removed, keep area secured until the work is finished and then reinstall the barricade or floor covering immediately.

17. Be Sure.

i. You know how to do the job in a correct, safe manner.

ii. You know the hazards and how to protect yourself.

iii. You ask the advice of your supervisor if you are not sure.

18. Firearms and explosives are prohibited within the NIF OCIP project areas, or on equipment and other facilities.

19. Do not try to place speed above safety. An efficient, safe worker is better than a speedy, careless one.

20. Throwing or dropping materials from one area or level to another is prohibited unless every precaution is taken to eliminate the possibility of damaging equipment or injuring persons.

21. Be alert for and heed all warning signs at all times.

22. When lifting heavy objects, the large muscles of the leg instead of the smaller muscles of the back shall be used. Get help on lifting all objects too heavy for one person.

23. Hard hats, safety glasses, and sturdy work shoes or boots shall be worn at all times. Inappropriate footwear or shoes with thin or badly worn soles shall not be worn. Other personal protective equipment such as gloves, goggles, respirators shall be worn when conditions require them for safety.

24. Observe good housekeeping. Keep work areas clear of debris and trash. Stack lumber and materials safely. Remove or bend nails from lumber, forms, etc.

25. Do not work or pass beneath suspended loads.

26. Only trained, qualified, and authorized persons shall install wiring or perform work or repairs on electrical equipment.

27. Excavations and trenches over 5 feet deep must be shored, sloped back, or a trench shield used to prevent cave-ins. A Competent Person must evaluate all excavations and trenches each day. Ladders are to be provided within 25 feet of workers in excavations and trenches 4 feet or deeper.

28. Work shall be so arranged that employees are able to face ladders and use both hands while climbing. Defective ladders shall not be used. Do not stand or sit 
on or above the top step or top cap. Extend ladders at least three feet above the walking surface. Secure ladders to prevent accidental movement.

29. No burning, welding, or other source of ignition shall be applied to any enclosed tank or vessel, even if there are some openings, until it has first been determined that no possibility of explosion exists, and authority for the work is obtained from the foreman or superintendent.

30. Any damage to scaffolds, falsework, or other supporting structures shall be immediately reported to the foreman and repaired before use.

31. Open sided floors, wall openings, floor holes, platforms, etc., more than 6 feet above the ground or floor must have standard guardrails or be covered.

32. Make sure handrails and walkways are in good repair and clear of tools, spare parts, and obstructions.

33. Workers exposed to fall hazards 6 feet or greater must be protected by a means of fall protection such as guardrails, nets, or personal fall arrest equipment such as a full body harness and shock absorbing.

34. All equipment shall be locked out and tagged to protect against accidental or inadvertent operation when such operation could cause injury to personnel.

\section{Hazardous Materials}

1. Material Safety Data Sheets (MSDS) are available through your supervisor for all chemicals, flammables, solvents, paints, and other hazardous products used on the project.

2. Label/mark all containers of flammable, combustible, hazardous, and toxic materials.

3. If employees observe sandblasting dust, asbestos fibers, smoke, or other possibly dangerous pollutants in the air of a work space, they shall contact their supervisors for instructions.

4. Employees shall cleanse thoroughly after handling hazardous substances, and follow special instructions from authorized sources.

5. No smoking when handling flammable materials.

6. Store flammable and combustible liquids away from other combustible materials, or in special flammable liquid storage lockers.

7. Gasoline shall not be used for cleaning purposes.

8. Smoking is prohibited at or in the vicinity of hazardous operations or combustible or flammable materials.

\section{Use of Tools and Equipment}

1. All tools and equipment shall be maintained in good condition. 
2. Damaged tools or equipment shall be removed from service and tagged "DEFECTIVE."

3. No guard, safety device, or appliance shall be removed from tools, machinery, or equipment except for the purpose of making repairs. Such removal shall only be done by persons qualified to make the repair, and they shall first disconnect any power source and have the tool, machinery, or equipment in a safe area. All guards and other protective devices shall be in their proper places and adjusted. Employees shall report promptly all deficiencies to their supervisor.

4. Pipe or Stillson wrenches shall not be used as a substitute for other wrenches.

5. Only appropriate tools shall be used for the job.

6. Wrenches shall not be altered by the addition of handle-extensions or "cheaters."

7. Files shall be equipped with handles and not used to punch or pry.

8. A screwdriver shall not be used as a chisel.

9. Wheelbarrows shall not be pushed with handles in an upright position.

10. Portable electric tools shall not be lifted or lowered by means of the power cord. Ropes shall be used.

11. Electric cords shall not be exposed to damage from vehicles.

12. Ground-Fault Circuit Interrupters (GFCI) are required on all temporary power circuits.

13. In locations where the use of a portable power tool is difficult, the tool shall be supported by means of a rope or similar support of adequate strength.

14. Compressed air shall not exceed 30 psi for cleaning purposes. Do not use pure oxygen for cleaning, especially on oily clothing!

\section{Machinery and Vehicles}

1. Only authorized persons shall operate machinery or equipment.

2. Loose or frayed clothing, or long hair, dangling ties, finger rings, etc., shall not be worn around moving machinery or other sources of entanglement.

3. Machinery shall not be serviced, repaired or adjusted while in operation, nor shall oiling of moving parts be attempted, except on equipment that is designed or fitted with safeguards to protect the person performing the work.

4. Engines shall be turned off before fueling.

5. Where appropriate, lockout procedures shall be used.

6. Employees shall not work under vehicles supported by jacks or chain hoists, without protective blocking that will prevent injury if jacks or hoists should fail.

7. Air hoses shall not be disconnected at compressors until hose line has been bled. 
8. All excavations shall be visually inspected before backfilling, to ensure that it is safe to backfill.

9. Excavating equipment shall not be operated near tops of cuts, banks, and cliffs if employees are working below.

10. Tractors, bulldozers, scrapers and carryalls shall not operate where there is possibility of overturning in dangerous areas like edges of deep fills, cut banks, and steep slopes.

11. When loading where there is a probability of dangerous slides or movement of material, the wheels or treads of loading equipment, other than that riding on rails, should be turned in the direction which will facilitate escape in case of danger, except in a situation where this position of the wheels or treads would cause a greater operational hazard.

12. Crowding or pushing when boarding or leaving any vehicle or other conveyance shall be prohibited.

13. Always look around equipment before starting to make sure no one is near moving parts, making inspections or adjustments.

14. Stand clear of hauling equipment that is being loaded or is dumping material.

15. Do not touch or guide moving cables or running wires with any part of your body. Keep your hands and fingers away from blocks and sheaves. Stand clear of all cables, wires and lines which are under strain.

\section{Roofing Operations}

1. Knotted hand lines should not be used.

2. Roofers tending kettles, or carrying buckets of hot tar, shall wear gloves that fit snugly at the wrists, and long sleeved shirts fastened at the wrists.

3. At no time should a roofer, while handling or exposed to injury from hot tar, work without a shirt or appropriate footwear.

4. Appropriate portable fire extinguishers shall be kept at or near the kettle, attached, if practicable, to the tongue of the kettle, away from the danger zone.

5. Kettle covers should be equipped with a handle that projects at least fourteen inches (14") away from the surface of the cover or lid.

6. Kettle covers shall be closed and latched when in transit and the kettle should be slop-proof when cover is closed.

7. When parked, means shall be provided to prevent inadvertent movement of the kettle.

8. Ladders should be used with great caution, and roof gutters should not be depended upon for support.

9. Workers handling buckets of hot tar should not carry anything that will interfere with the safety of this operation. 
10. The gallows frame shall be securely anchored before hoisting materials.

11. Only muscular power shall be used to hoist materials by means of a gallows frame. A winch or power hoist shall not be used. 


\section{NIF PROJECT}

FORM S+H A-1—SAFETY RULES TRAINING, ORIENTATION, AND DOCUMENTATION

I, understand the National Ignition Facility OCIP Construction Safety. Rules.

hereby acknowledge that I have received training and 


\section{Personal Protective Equipment}

It is the responsibility of supervisors and foremen to provide all employees with directions about employer-provided and employee-provided protective equipment necessary for each operation. Personal protective equipment shall be worn as required by LLNL safety requirements, Federal OSHA, and California OSHA. The requirements set forth herein pertaining to personal protective equipment shall apply at all locations, whether permanent or temporary. It is the contractor's responsibility to provide personal protective equipment to its employees, and to ensure proper use wherever necessary.

Personal protective equipment shall be use to reduce the potential for injuries or detrimental affects on health, which are not controllable by engineering or administrative means, to all employees. The use of personal protective equipment for protection from identified hazards is mandatory under the following conditions:

1. Where required by law or LLNL policy.

2. Where exposure to the hazard has the potential for injury or illness to an employee.

3. Where there is a potential for damage or contamination to property or the environment.

4. Where the failure to utilize the equipment would expose non-employees to a safety or health hazard.

The mandatory use of personal protective equipment will apply to all visitors in areas where use of such equipment is required.

\section{Responsibilities}

\section{NIF Construction Contractors/Subcontractors}

1. All contractors/subcontractors shall use the protective equipment prescribed by the regulatory authorities, such as CAL/OSHA and contractors rules and regulations to control or eliminate any hazard or other exposure to illness or injury. Any employee who willfully refuses to use the prescribed protective equipment designed to protect him or her or willfully damages such equipment shall be subject to disciplinary action which may lead to his or her immediate termination. As needed, contractors/subcontractors shall provide personal protective equipment needed to their employees.

University Employees and non-LLNL Employees (reference Section I.A.14 for definitions)

1. All LLNL employees and non-LLNL employees (including contract labor, supplemental labor, vendors, personnel matrixed/assigned from other National Laboratories, participating guests, visitors and students) at a minimum shall 
comply with the LLNL Environment, Safety, and Health Program and applicable requirements of the NIF Construction Safety Program.

\section{Exceptions}

Requests by NIF Construction Contractors/Subcontractors for exceptions/modifications to LLNL safety requirements will only be approved if equivalent safety is demonstrated and OSHA requirements are met. Approvals shall be issued in writing by the cognizant Construction Manager (or Deputy Associate Project Engineer for Construction) with concurrence from LLNL's Safety Representative for the NIF project.

\section{Basic NIF PPE Requirements}

Ear Plugs or Muffs. The use of hearing protection is mandatory where workplace daily noise levels exist with the possibility that employees receive exposure in excess of the allowable noise. The hearing protection devices chosen for use must conform to all applicable federal, state, and local safety and health regulations.

Eye Wear, Goggles, Safety Glasses, Face Shield, and Helmets. This could include, but not be limited to, grinding, chipping, sanding, sandblasting, or use of chemicals. Safety glasses or face shields must conform to the American National Standards Institute (ANSI), Standard for Occupational and Educational Eye and Face Protection, Z87.1. Welding shields or goggles shall be worn by personnel doing cutting or welding.

Eye protection shall be worn at all times, except in administrative areas. Approved welding helmets and appropriate protective eye wear is required onsite by all contractors during machinery activities which require appropriate protection.

Hard hats are required in all construction areas. Hard hats shall be worn at all times in construction areas, except in administrative areas. The head protection devices shall meet the specifications contained in the American National Standards Institute, Z89.1, Requirements for Industrial Head Protection.

Hard hats for the protection of employees exposed to high voltage electrical shock and burns shall meet the specification contained in American National Standards Institute, Z89.2. All employees and visitors must wear company approved hard hats during work hours while inside construction areas.

Respirators. When it is determined that effective engineering control of oxygen deficiency or air contaminant exposure is not feasible, appropriate respiratory protection will be provided for use by the exposed employees. Use will be mandatory whenever a potential respiratory hazard exists. 
The selection, use, and maintenance of respirators shall comply with all applicable state/federal, ANSI Z88.2 and local laws pertaining to safety and health. Approved respirators (MSHA) will be used when excessive dusts, mists, fumes, gases or other atmospheric impurities are determined to be harmful to health. Contractors are responsible to provide a written respiratory protection program to Construction if respirators are on-site.

Safety Harnesses and Lifelines. Full body safety harnesses will be used by all employees working from unguarded surfaces where falls to a different level GREATER THAN SIX (6) FEET present a hazard. Safety Belts will not be allowed; only the use of a full body harness and shock absorbing lanyard, or chain positioning lanyard will be acceptable. The project will be a $100 \%$ tie off project, requiring the use of two lanyards when exposed to a fall greater than six(6) feet.

Footwear. All employees working in construction areas should wear sturdy work shoes or boots. In areas where there is danger of falling objects, hard toe safety boots or shoes shall be worn.

Gloves. Strong nonslip gloves are recommended for all workers, except when wearing them could create greater risks

Dress Code. Employees working in construction areas are required to wear clothing for the appropriate season. Shirts shall have a minimum of 4" sleeves. Tank tops and sleeveless shirts are not allowed. Pants should be long enough to cover the top of appropriate foot wear. Winter clothing should be sufficient to protect against cold related injuries, i.e., hypothermia and frostbite.

Special Equipment. As heretofore stated, the use of personal protective equipment will be deem mandatory when the hazard cannot be controlled at the source. This shall apply to the use of special protective equipment such as gloves, aprons, sleeves, shoes, hoods, and boots. When it has been determined through the site management, statistical analysis, or compliance requirements that the use of special protective equipment is needed to provide the hazard control, this mandatory use requirement shall apply. 


\section{Hazardous Material Control}

These rules apply to all contractors and vendors, including employees with supervisory and non-supervisory assignments. The General Safety and Health rules shall be used by management to promote accident prevention through indoctrination, safety and health training and on-the-job application.

As a condition for contracts award, all contractors and subcontractors and their employees must certify on Form S \& H A-2, that they have read and understand, or have been briefed and understand, the National Ignition Facility OCIP Project General Safety Rules. (An interpreter must brief those employees who do not speak or read English fluently.)

\section{Responsibilities}

NIF Construction Contractors/Subcontractors

1. Health Hazard Communication Plan

A written plan for compliance with state and federal worker right-to-know laws is a requirement to be submitted by the contractor to the NIF Project Manager. This plan shall include specific safety responsibilities for all levels of management and for the employee.

2. Identification

Chemicals, paints, solvents, adhesives, etc. may be used in the course of construction. An inventory of all potentially hazardous materials shall be available on site in the construction office, along with a MSDS for each material. These shall be available at all times to employees, LLNL inspectors, and other persons affected by the materials (e.g., other subcontractors on the same job site). All containers shall be labeled describing the product's identity, its hazards, and first-aid procedures to follow in the event of an emergency.

3. Worker Notification

Before using any hazardous material, each worker shall be aware of the requirements of this section and be trained in the proper use, disposal, and special handling procedures to be followed for each material (e.g., when respirators are to be worn).

4. Handling

While handling hazardous chemicals or solvents, employees shall follow directions and comply with any warnings or cautions affixed to the labels. Any questions concerning the use of such chemicals and personal protective equipment shall be directed to the supervisor. 


\section{Disposal}

The subcontractor is responsible for proper disposal, in accordance with Federal, State, and Local regulations, of chemical and hazardous waste generated by the subcontractor in the performance of this subcontract. Preexisting hazardous material removed and discarded as waste by the subcontractor in the performance of this subcontract shall be disposed of by LLNL.

University Employees and non-LLNL Employees (reference Section I.A.14 for definitions)

1. All LLNL employees and non-LLNL employees (including contract labor, supplemental labor, vendors, personnel matrixed/assigned from other National Laboratories, participating guests, visitors and students) at a minimum shall comply with the LLNL Environment, Safety, and Health Program and applicable requirements of the NIF Construction Safety Program.

\section{Exceptions}

Requests by NIF Construction Contractors/Subcontractors for exceptions/modifications to LLNL safety requirements will only be approved if equivalent safety is demonstrated and OSHA requirements are met. Approvals shall be issued in writing by the cognizant Construction Manager (or Deputy Associate Project Engineer for Construction) with concurrence from LLNL's Safety Representative for the NIF project.

\section{Hazard Material \& Waste Management Guidelines For NIF Contractors}

\section{Hazard Communication}

The Hazard Communication Standard (HCS) as mandated by CAL/OSHA is contained in GISO 5194. As outlined within the Standard, employers are responsible for evaluating hazards of all chemicals, and transmitting information concerning the hazards to affected employees. Information is transmitted by means of a Hazard Communication Program. The Hazard Communication Program shall contain the following elements:

\section{A. Hazard Communication Program Guidelines}

1. Written Hazard Communication Program - 5194(e)

Employers must develop, implement and maintain at the workplace a Hazard Communication Program to describe how the following elements will be met. In addition, the following must be included:

a. A list of the hazardous chemicals known (or suspected) to be present at the site, with reference to the Material Safety Data Sheet.

b. Methods to be used to inform employees of the hazards of non-routine tasks. 
NOTE: Employers who produce, use or store hazardous chemicals in such a way that the employees of other contractors may be exposed shall additionally ensure that the Hazard Communication Program developed includes the following:

a. MSDS sheet copies to the Construction Management central file. This method will be utilized to provide the other contractors with the necessary information from the MSDS;

b. Method to be used to inform employees of steps to be taken to protect employees during normal operations and in foreseeable emergencies; and,

c. Methods to be used to inform the other employees of the labeling system used in the workplace.

2. Labels and Other Forms of Warning - 5194(f)

The Employer shall ensure that each container of hazardous chemicals in the workplace is labeled, tagged or marked with the identity of the hazardous chemical(s) and appropriate hazard warnings, and in accordance with 5194(f).

3. Material Safety Data Sheets (MSDS) - 5194(g)

Employers must maintain a MSDS for each hazardous chemical they use. Specific MSDS information is contained in 5194(g). Additional contractor responsibilities for MSDSs include:

a. Maintain copies of the MSDSs for each hazardous chemical in the workplace, and ensure that they are readily accessible to employees in their work area; and,

b. The MSDSs may be kept at a central location as long as employees can immediately obtain the required information in an emergency.

4. Employee Information \& Training - 5194(h)

Employers must provide employees with information and training on hazardous chemicals in their work area at the time of initial assignment and whenever a new hazard is introduced.

Information must include:

a. The requirements of the Hazard Communication Standard;

b. Any operation in their work area where hazardous chemicals are present; and,

c. The location and availability of the written program, including the list(s) of hazardous chemicals and MSDSs.

Training must include:

a. Methods that may be used to detect the presence or release of hazardous chemicals in the work area;

b. The physical and health hazards of the chemicals in the work area;

c. Personal protective measures and equipment; and, 
d. Specific details of the employers Hazard Communication Program. Employee training for this requirement will be documented and acknowledged by employee signatures following each session using Form $\mathrm{S}+\mathrm{H} \mathrm{A}-2$ at the end of this Section or as acknowledged on OCIP registration.

\section{B. Specifications For Hazard Communication Program Submittal}

The Contractor shall submit (to Construction Management) a copy of the MSDS inventory thirty (30) days prior to on-site construction activities. Following review of the MSDSs, the MSDSs will be incorporated into a central registry.

1. Hazard Communication Central File

A central file shall be set-up at Construction Management offices to maintain Hazard Communication Program information in a principal location for use in emergency situations (i.e., spill, fire, employee exposure).

Construction Management will review the Hazard Communication Program and pertinent information will be compiled into the file. The file will be maintained and updated for the duration of the project.

2. Audit and Review

It is the responsibility of the Contractor's Safety Representative to review his employees Hazard Communication Program on at least an annual basis. All revisions and updates shall be incorporated to reflect changes in the purchase, use, storage and handling of hazardous chemicals at the construction site.

It is also the responsibility of the Contractor's Safety Representative to periodically audit procedures in the use of hazardous materials and to institute corrective action where required to meet the requirements of the Standard. 


\section{HAZARD COMMUNICATION TRAINING DOCUMENTATION}

\section{SAMPLE FORM S+H A-2}

I, communication training as required by CALOSHA 5194 on hereby acknowledge that I have received hazard the law, the chemicals I may be exposed to (to include the hazards and their controls), how to use a Material Safety Data Sheet, where the MSDSs, chemical list, and the written program may be found, and the proper detection, first aid, and spill control procedures.

EMPLOYEE SIGNATURE SIGNATURE

GENERAL CONTRACTOR NAME
CONTRACTOR TRAINER

SUBCONTRACTOR NAME 


\section{Hazardous Material \& Waste Management Guidelines}

A. Hazard Assessment

1. Hazardous Materials

A hazardous material as defined in CAL OSHA's Directors list as a material which exhibits one or both of the following:

a. Physical Hazard-Flammable, combustible, compressed gas, explosive, reactive, etc., or

b. Health Hazard-Toxic, highly toxic, irritant, corrosive, etc.

Hazardous materials are most easily identified through manufacturer information by way of container labeling and Material Safety Data Sheets (MSDS). In addition, hazardous materials can be identified through specific systems developed by agencies such as OSHA's Labor Code section 6382, the Department of Transportation (DOT), California EPA and the National Fire Protection Association (NFPA). All hazardous materials arriving on-site must be labeled according to guidelines established through OSHA GISO 5194.

All trucks transporting hazardous materials on, off, or at the Site must be labeled and/or display a placard according to DOT specifications. DOT information on proper shipping names and placard is contained in 49 CFR 172.101.

Each Contractors Hazard Communication Program will be made available to the Lab's Fire Department, if so requested.

2. Hazardous Wastes

The Environmental Protection Agency (EPA) defines hazardous waste as a discarded commercial product, off-specification material, container residue, spill residue, or hazardous material declared a waste by the generator. EPA provides criteria for identifying and listing hazardous waste.

Characteristics of hazardous wastes are defined as wastes which exhibit characteristics of ignitability, corrosiveness, reactivity, or toxicity.

The contractor is responsible for the identification and proper use of hazardous materials and the elimination of hazardous waste on-site, as stipulated through and in accordance with all Federal, State, and Local regulations.

B. Non-Hazardous, Hazardous Material And Hazardous Waste Management

1. Acceptance and Storage of Hazardous Materials

When the schedule for performance of the work is submitted after contract award, submittal of the Hazardous Materials and Waste Management Plan is to be provided to Construction Management and NIF. This provides data regarding anticipated quantities, storage, disposal, spill prevention and clean- 
up methods, and contingency planning as it relates to hazardous materials and hazardous waste.

Construction Management and the NIF may share this information with the Hazards Control Department's Emergency Management Division (LLNL Fire Dept.) and ES\&H Team 2 for review.

General storage and/or lay down areas will be assigned by the LLNL Fire Department and ES\&H Team 2. Storage within these areas shall be in accordance with applicable Federal, State and local regulations.

2. Non-Hazardous Material Handling, Storage and Disposal

Non-Hazardous materials are classified as materials which do not exhibit physical or health hazards, such as general construction debris.

Contractors will place all non-hazardous waste (trash, rubbish, etc.) in dumpsters. Nonhazardous waste is not allowed to accumulate in the work area, and should be removed at the end of every shift. Trash should be placed in dumpsters provided by the designated trash collector.

The contractor is responsible for maintaining storage areas in a clean and safe condition. If the area is unacceptable, the Project Manager may require a clean-up of the area at the expense of the contractor.

3. Hazardous Material Handling and Storage

All site personnel required to work with or have a potential for being exposed to hazardous materials, shall obtain approval through site management for such operations, have appropriate training, and the contractor shall provide all necessary personal protective equipment and/or engineering controls to prevent exposures.

All hazardous material storage areas will be equipped with appropriate containment measures, safety equipment, and spill clean-up materials as required by Federal, State, and local regulations. In addition, all flammable materials are to be stored according to specific requirements designated by NFPA 30 and LLNL Fire Department regulations.

Bulk containers of hazardous materials, including 55-gallon drums containing fuels and oils, will not be allowed to be stored on-site. Any operations concerning hazardous materials storage must be cleared through the LLNL Fire Department and ES\&H Team 2 prior to any on-site operations.

Waste materials are not to be stored with usable material. Tools, clothing, and similar materials which are not hazardous or are not required for safe handling or spill clean-up of hazardous materials are to be kept in the storage area. Incompatible materials are not to be stored together. Review of the appropriate MSDS will provide information regarding specific storage requirements, as well as incompatible materials and special requirements.

4. Hazardous Waste Storage

Permanent or long-term hazardous waste storage will not be allowed within the Lawrence Livermore Lab. All operations regarding temporary hazardous 
waste storage within regulatory time limits will be cleared through construction Management, the LLNL Fire Department and ES\&H Team 2 prior to approval. All quantities of waste must be tracked and handled in accordance with Federal, State, and local regulations.

5. Hazardous Waste Disposal

Hazardous waste must be containerized and stored separately, with subsequent disposal in accordance with all Federal, State and local regulations.

Notification should be made to Construction Management and NIF Management when waste is scheduled to be removed off-site. Information regarding the disposal method and/or destination of the waste may be requested by the Project Manager. Waste materials (not generated on-site) are not to be brought onto the site.

Waste transportation or disposal contractors will not be allowed on-site without notification to and approval from Construction Management and NIF management.

6. Management of Empty Containers

Empty containers are to be cleared from the work area daily. Container reuse is acceptable based on the following provisions:

a. The original material contained was not toxic, flammable or combustible.

b. The identity of the new contents are clearly identified using all applicable labeling requirements.

c. The new material being placed into the container is not a hazardous material (i.e., trash, scrap metal, etc.) or a hazardous waste.

7. Specific Provisions for Petroleum Based Materials

Petroleum based materials are substances such as fuel, diesel, oils, or lubricants.

Bulk storage of petroleum based materials is not allowed on-site.

8. Removal of Unused Material and Partially Filled Containers From the Site Hazardous Material.

All hazardous materials shall be removed from the site on a daily basis following completion of each phase of work or as soon as through with material.

The Project Manager may request information regarding material identity, destination, responsible party, and manner of transportation prior to removal off-site. Information requested may include an affidavit from the contractor confirming the material is a product and not a waste material.

Hazardous material is not to be abandoned on-site. If material is found on the site and can be traced to a contractor, the contractor shall be required to remove the material, or will be responsible for all expenses incurred for moving and disposal of the material. 
The contractor is responsible for the proper clean up and/or decontamination of assigned areas. Failure to do so, will result in contractor incurring all expenses for the clean up and/or decontamination.

\section{Environmental Incident}

An environmental incident involves a release or potential release of a hazardous substance that can pose a substantial danger to employees, public health and welfare, or the environment. An effective response depends on an accurate evaluation of the incident, notification to outside agencies (as applicable), and development of an effective course of action. Any incident situation represents a potential threat to employees, the public, or the environment. For environmental incidents at the NIF construction site, all precautions will be taken to remedy the situation in a safe manner.

1. Hazard Identification and Assessment

Initial hazard identification can be performed through a standardized identification system such as:

a. National Fire Protection Association (NFPA) 704-M System

b. Department of Transportation (DOT) Hazard Identification System

This allows immediate hazard identification through visual examination of a label, placard or sign. Contractors are responsible to train employees on the specific identification system that will be utilized on the project. In addition immediate access to MSDSs must be available in the central file, the MSDS provides extensive information that is critical in an incident situation. Contractors and subcontractors are required by the Hazard Communication Standard to maintain MSDSs so they are readily accessible for each work shift.

Through the hazard identification and assessment, the incident can be categorized into either an emergency or non-emergency environmental incident.

c. An emergency incident is considered an incident which presents a potential for harm to personnel or the environment, the contractor is unable to immediately control the situation, and/or the spill exceeds the reportable quantity. Emergency assistance shall be immediately requested by dialing 911 or from a cellular telephone $447-6880$.b. A non-emergency incident is defined as an incident which does not present potential harm to personnel and/or the environment, the contractor has the capability to immediately control the situation, and/or the spill is less than the reportable quantity. IF any question exists ES\&H Team $2(x 2-6126)$ is to be immediately contacted.

2. Environmental Incident Management

Environmental Incident Management Procedures will adhere to the LLNL Hazardous Spill/Emergency Response Plans.

Notification to the media will flow through LLNL Public Affairs Office only. 


\section{Traffic Control}

These rules apply to the NIF construction site and adjacent areas of LLNL.

Traffic control and routes are as indicated on the construction drawings and outlined in the written instructions. Sketches for the construction of certain detours in areas not indicated on the drawings shall be submitted to NIF Construction Management for approval. Personnel are directed to become familiar with these details.

Required safety, fire, instructional, and traffic signs shall be posted and obeyed. They shall not be removed until their removal is approved by the construction manager or Program construction coordinator.

All flagmen shall wear blaze orange vests.

\section{Responsibilities}

NIF Construction Contractors/Subcontractors

All Construction Contractors/Subcontractors employees shall comply with the LLNL Traffic Safety Policy and Chapter 35 of the LLNL Health \& Safety Manual.

University Employees and non-LLNL Employees (reference Section I.A.14 for definitions)

1. All LLNL employees and non-LLNL employees (including contract labor, supplemental labor, vendors, personnel matrixed/assigned from other National Laboratories, participating guests, visitors and students) at a minimum shall comply with the LLNL Traffic Safety Policy, Chapter 35 of the LLNL Health $\mathcal{E}$ Safety Manual, and applicable requirements of the NIF Construction Safety Program.

\section{Exceptions}

Requests by NIF Construction Contractors/Subcontractors for exceptions/ modifications to LLNL safety requirements will only be approved if equivalent safety is demonstrated and OSHA requirements are met. Approvals shall be issued in writing by the cognizant Construction Manager (or Deputy Associate Project Engineer for Construction) with concurrence from LLNL's Safety Representative for the NIF project. 


\section{Fire Prevention}

These rules apply to the NIF construction site and adjacent areas of LLNL.

\section{Responsibilities}

\section{NIF Construction Contractors/Subcontractors}

All Construction Contractors/Subcontractors employees shall comply with the following LLNL requirements.

1. Hot Work Operations

A Hazardous Work Permit, which is issued by the Hazards Control

Department's Emergency Management Division (LLNL Fire Dept.), is required for all hot work operations. Hot work operations include cutting, welding, brazing, soldering, roofing or road work using tar pots, torches and hot air guns used in applying roofing, thermal spraying, or any similar activity. The requirements of the Permit shall be followed without exception. The supervisor, construction inspector or construction manager must contact the LLNL Fire Department to arrange for the permit. A single "blank" permit may be requested to cover long term phases of the project, such as conventional facility construction..

2. Smoking

Smoking is prohibited at or in the vicinity of hazardous operations or combustible or flammable materials. "No Smoking" signs shall be posted in these areas. Smoking will be allowed only in designated areas. Where smoking is permitted, safe receptacles shall be provided for smoking materials.

3. Waste Disposal

Accumulations of combustible waste material, dust, and debris shall be removed from the structure and its immediate vicinity at the end of each work shift, or more frequently as necessary for safe operations. Good housekeeping shall be maintained, and access will be kept clear at all times. If portable dumpsters are provided for waste disposal, they shall be located at least $25 \mathrm{ft}$ from any structure.

4. Fire Alarm Reporting

Telephone service for reporting fires to the LLNL Emergency Dispatch Center (911 or 447-6880 from a cellular telephone or non-LLNL telephone) shall be readily available near the premises. Instructions shall be issued to notify the LLNL fire department immediately in case of fire, including those already extinguished by construction site personnel. The LLNL fire department number shall be conspicuously posted near each telephone. 
5. Access for Fire fighting

All-weather roads for fire fighting equipment shall be maintained. Fire hydrants and fire department connections shall be kept clear of any obstructions.

6. Fire Extinguishers

Fire extinguishers shall be located on or adjacent to:

- Storage sites of combustibles.

- Fuel dispensing vehicles.

- Sites of hot work operations.

- The supervisor's vehicle.

- The supervisor's office or shed.

In addition, at least one approved extinguisher shall be provided in plain sight on each floor at each usable stairway where combustible material could accumulate. Extinguishers shall be placed within the structure so that the maximum travel distance to an extinguisher is no more than $75 \mathrm{ft}$.

7. Solvents

Flammable or combustible solvents shall not be used for cleaning purposes without specific instructions from the supervisor and such instructions shall include the site and conditions of such use. Waste solvents shall be managed according to Federal, State, and Local regulations.

University Employees and non-LLNL Employees (reference Section I.A.14 for definitions)

1. All LLNL employees and non-LLNL employees (including contract labor, supplemental labor, vendors, personnel matrixed/assigned from other National Laboratories, participating guests, visitors and students) at a minimum shall comply with the LLNL Environment, Safety, and Health Program, Chapter 25 of the LLNL Health \& Safety Manual, and applicable requirements of the NIF Construction Safety Program.

\section{Exceptions}

Requests by NIF Construction Contractors/Subcontractors for exceptions/modifications to LLNL safety requirements will only be approved if equivalent safety is demonstrated and OSHA requirements are met. Approvals shall be issued in writing by the cognizant Construction Manager (or Deputy Associate Project Engineer for Construction) with concurrence from LLNL's Safety Representative for the NIF project.

\section{NIF Construction Site Fire Prevention and Control Rules}

a. Cleaning_Agents. Explosive liquids will not be used as cleaning agents. Use only approved cleaning fluids. 
b. Combustible Materials. Gasoline and similar combustible liquids will be stored in secure approved containers and in an area free from burning hazards.

c. Combustible Materials. Keep all heat sources away from combustible liquids, gases or other flammable materials. When not in use, store combustible materials in a well ventilated, cool place.

d. Fire Extinguisher. Do not remove or tamper with fire extinguisher installed on equipment or vehicles or in other locations unless authorized to do so or in case of fire.

e. Fire Fighting Equipment. Fire fighting equipment must be kept free from obstacles, equipment, materials and debris that could delay emergency use of such equipment. Familiarize yourself with the location and use of the project's fire fighting equipment.

f. Oily Rags and Waste. Discard and/or store all oily rags, waste and similar combustible materials in metal containers on a daily basis. Rags and other waste materials saturated with oil, fuels, or solvents must be managed as hazardous waste.

g. Safety Cans. Handling of all flammable liquids by hand containers will be in approved type safety containers with spring closing covers and flame arrestors.

h. Smoking and Fires. Extinguish all matches, cigarettes, cigars and pipe tobacco before discarding. Do not smoke while fueling equipment or while in close proximity to refueling areas. Never leave open fires unattended.

i. Storage. Storage of flammable substances on equipment or vehicle is prohibited unless such unit has adequate storage area designed for such use.

j. Types of Fires.

i. Class A (wood, paper, trash) - use water or foam extinguishers.

ii. Class B (flammable liquids, gas, oil, paints, grease) - use foam, $\mathrm{CO} 2$ or dry chemical extinguisher.

iii. Class C (electrical) - use $\mathrm{CO} 2$ or dry chemical extinguisher. 


\section{Sanitation and First Aid}

These rules apply to the NIF construction site and adjacent areas of LLNL.

\section{Responsibilities}

NIF Construction Contractors/Subcontractors

All Construction Contractors/Subcontractors employees shall comply with the following LLNL requirements.

1. Toilet facilities shall be provided by the Construction Manager for the specific NIF Element.

2. Bottled drinking water and disposable cups shall be provided, along with a container for the disposal of used cups. This drinking water shall be conveniently placed in the area of the work site.

3. Proper ventilation shall be maintained in order to avoid possible harmful buildup in areas where toxic fumes, dust, vapors, or gases may be produced. Respiratory protection shall be supplied when adequate ventilation cannot be provided.

4. First-aid kits shall be placed in the field office and carried in the Superintendent's vehicle. First-aid equipment shall be inspected regularly for completeness, and an employee qualified in first aid shall be on site during the normal work shift.

5. The emergency phone number card, in addition to being posted on the project bulletin board, shall be posted prominently in work areas and carried in each superintendent's vehicle. Depending on the nature of the accident and the first aid or medical care required, the necessary assistance shall be requested by phoning the emergency number ( 911 or $447-6880$ from a cellular telephone or non-LLNL telephone) indicated on the card.

University Employees and non-LLNL Employees (reference Section I.A.14 for definitions)

1. All LLNL employees and non-LLNL employees (including contract labor, supplemental labor, vendors, personnel matrixed/assigned from other National Laboratories, participating guests, visitors and students) at a minimum shall comply with the LLNL Environment, Safety, and Health Program and applicable requirements of the NIF Construction Safety Program.

\section{Exceptions}

Requests by NIF Construction Contractors/Subcontractors for exceptions/modifications to LLNL safety requirements will only be approved if equivalent safety is demonstrated and OSHA requirements are met. Approvals shall 
be issued in writing by the cognizant Construction Manager (or Deputy Associate Project Engineer for Construction) with concurrence from LLNL's Safety Representative for the NIF project.

\section{NIF Construction Sanitation \& First Aid Rules}

a. Accident. Avoid unnecessary moving of an injured person. Notify first aid immediately and keep the injured person as comfortable as possible until first aid personnel arrive.

b. Burns. Immediately treat acid, caustic and thermal burns by flushing with cold water, then report promptly to first aid.

c. Drinking Cups. Do not drink out of a common dispensing cup or ladle. Use only drinking fountains or individual disposable cups.

d. Drinking Water. Drink water that is specifically supplied and marked for drinking purposes. Stream or river water may look clear and clean but may contain deadly contaminants.

e. Electrical Shock. Turn electric power off, or use a dry board, stick or other nonconducting object to remove the contact from the victim. Do not touch the victim until he is free from current contact.

f. Hygiene. Personal cleanliness is extremely important. Many skin irritations result from careless or incomplete washing or bathing. Wash thoroughly and dry the skin completely to eliminate skin rashes, irritations and infections.

g. Redressing. If it is necessary to have an injury redressed, report to first aid and to your supervisor immediately.

h. Reporting. Report all injuries, no matter how slight, to first aid and to your supervisor immediately.

i. Treatment. Follow all advice given by trained first aid attendants, nurses or physicians relating to your injury. 


\section{Confined Space Safety Requirements}

The control of hazards posed by entry/work in confined spaces shall be based upon the requirements outlined in the LLNL Health \& Safety Manual Supplement 26.14 ("Working in Confined Spaces"), Federal OSHA, and California OSHA.

\section{Responsibilities}

NIF Construction Contractors/Subcontractors

1. As needed, contractors/subcontractors shall provide equipment needed to work in confined spaces. Examples of such equipment include, but is not limited to:

- Barricades, ropes, tapes, and similar items used to limit access,

- Ground fault circuit interrupters,

- Explosion-proof voltage lamps and other equipment needed to work safely in confined spaces that may contain potentially hazardous atmospheres,

- Devices for providing mechanical ventilation in confined spaces,

- Atmospheric testing instruments,

- Harnesses and rescue devices,

- Respirators, including supplied air respirators and SCBAs, breathing-quality air sources, and supplies/equipment needed to keep it in working condition

- Other personal protective equipment,

- Devices to block the flow of hazardous materials or energy into the confined space including blanks for piping and lock out/tag out equipment, and other items,

- Equipment for inerting spaces, as needed.

2. As required, contractors/subcontractors shall implement and maintain a confined space program. This program contains a permit system using their own personnel and permits, and the capability to safely work in confined spaces. Examples of capabilities needed to work in confined spaces include, but are not limited to the capability to:

- Identify confined spaces

- Evaluate confined and classify confined spaces

- Determine what atmospheric testing is needed for which substances and when, and

- Develop and implement appropriate precautions using their own personnel or subcontractor. 
The contractor's/subcontractor's confined space program shall be reviewed and approved prior to implementation on the NIF site by the NIF Field Construction Manager (or Deputy Associate Project Engineer for Construction) with concurrence from the LLNL Safety Representative for NIF.

3. All contractors/subcontractors shall train their personnel to work in confined spaces and perform the duties required by Federal/California OSHA requirements. Examples of this training include, but are not limited to:

- Confined Space Entrant training,

- Confined Space Attendant training

- Training about how to conduct measurements prior to and during work in confined spaces,

- Training about how to prepare hot work permits for fire-hazardous work in confined spaces,

- Training about how to use and service respirators

Evidence of this training shall be delivered to Construction Management for filing.

4. The contractor shall coordinate rescue arrangements with the LLNL Fire Department. The University will provide emergency communications equipment, as needed, and guidance about how to notify and work with the LLNL Fire Department in an emergency. The University will provide guidance about acceptable radio and electronic communications devices used to communicate with workers in confined spaces.

5. All contractors/subcontractors creating a confined space hazard shall ensure that proper controls and warnings (e.g., signs, locks, barriers, etc.) are used to inform employees of the hazard and restrict inadvertent access to the confined space.

University Employees and non-LLNL Employees (reference Section I.A.14 for definitions)

1. All LLNL employees and non-LLNL employees (including contract labor, supplemental labor, vendors, personnel matrixed/assigned from other National Laboratories, participating guests, visitors and students) at a minimum shall comply with the LLNL Health \& Safety Manual Supplement 26.14 (Working in Confined Spaces).

\section{Exceptions}

Requests by NIF Construction Contractors/Subcontractors for exceptions/modifications to requirements in the LLNL Health \& Safety Manual Supplement 26.14 (Working in Confined Spaces) will only be approved if equivalent safety is demonstrated and OSHA requirements are met. Approvals shall be issued in writing by the cognizant Construction Manager (or Deputy Associate Project Engineer for Construction) with concurrence from LLNL's Safety Representative for the NIF project. 
8. (Reserved) 


\section{Ladders and Stairways}

All ladders and stairways shall be built, used, and maintained in a safe manner to prevent injury to workers. The control of all ladders and stairways shall be based upon LLNL safety requirements, Federal OSHA, and California OSHA.

\section{Responsibilities}

NIF Construction Contractors/Subcontractors

1. All contractors/subcontractors must establish a ladders and stairway safety program to ensure compliance with LLNL requirements, Federal OSHA, and California OSHA.

2. All contractors/subcontractors are responsible to develop, document, and utilize ladders and stairway safety procedures as required.

3. All contractors/subcontractors are responsible to instruct their employees in the safe use of ladders and stairways, and maintain a record thereof. Training records for contractors/subcontractors employees shall be delivered to Construction Management for filing.

4. All contractors/subcontractors must conduct daily inspections of ladders and stairways under their control to ensure that the requirements of the ladder and stairway safety program are being followed.

University Employees and non-LLNL Employees (reference Section I.A.14 for definitions)

1. All LLNL employees and non-LLNL employees (including contract labor, supplemental labor, vendors, personnel matrixed/assigned from other National Laboratories, participating guests, visitors and students) at a minimum shall comply with LLNL ladder and stairway use safety policy.

\section{Exceptions}

Requests by NIF Construction Contractors/Subcontractors for exceptions/modifications to LLNL ladder and stairway safety requirements will only be approved if equivalent safety is demonstrated and OSHA requirements are met. Approvals shall be issued in writing by the cognizant Construction Manager (or Deputy Associate Project Engineer for Construction) with concurrence from LLNL's Safety Representative for the NIF project.

\section{Basic Rules for Ladder and Stairway Safety}

1. Employees required to use ladders and stairways shall be trained in their safe use and in the recognition of hazards related to them. 
2. No employee shall use a ladder that is defective or does not meet OSHA requirements. Defective ladders shall be tagged "Do Not Use" and removed from service immediately.

3. Wooden ladders shall not be painted. They may be treated with linseed oil.

4. Ladders shall not be tied or fastened together.

5. Work shall be arranged so that employees are able to face ladders and use both hands while climbing.

6. The use of ladders to transport heavy or awkward-shaped items is prohibited. Ladders shall not be overloaded by persons or materials.

7. Step ladders shall never be used as straight ladders. They shall be fully opened at all times except when in storage. Employees shall not be allowed to stand on the top step or end cap of step ladders.

8. Straight ladders shall be positioned with the base set back a distance equal to approximately one fourth of the height of the ladder to its bearing point. The ladder shall extend at least three feet above the landing. The ladder must be secured to prevent it being displaced.

9. Face the ladder and use both hands when going up and down ladders.

10. When using a ladder, workers must not extend themselves to the sides such that their torso is beyond the siderail of the ladder.

11. Materials and tools should be raised and lowered by a rope or other mechanical means.

12. Select the right ladder for the job.

13. Stairways shall meet OSHA requirements.

14. When using stairways, do not run, skip stairs, or slid on handrails. 


\section{Scaffolding and Lift Safety}

All scaffolding and lifts shall be erected, used, maintained, and disassembled in a safe manner to prevent injury to workers, collapse or tip over. The control of all scaffolds and lifts shall be based upon LLNL scaffolding and lift safety requirements, Federal OSHA, and California OSHA.

\section{Responsibilities}

\section{NIF Construction Contractors/Subcontractors}

1. All contractors/subcontractors must establish a scaffolding and lift safety program to ensure compliance with LLNL requirements, Federal OSHA, and California OSHA.

2. All contractors/subcontractors are responsible to develop, document, and utilize scaffolding and lift safety procedures as required.

3. Before erecting any scaffold that is more than three stories tall (greater than 36 feet), the subcontractor shall submit to the Construction Manager for review and approval a detailed written plan showing the design of scaffolding, bracing, attachment to the structure, maximum loading, or other provisions to be made to protect workers from the hazard of scaffolding collapse or tip over. The proposed plan shall comply with the standards established by State of California, CCR Title 8, and California Building Standards Code (CBSC)(formerly CCR Title 24). If the detailed plan varies from such scaffolding system standards, it shall be prepared by a California registered civil or structural engineer whose name and registration number shall be indicated on the drawings. If a dispute arises as to whether the plan shall be prepared by a registered civil or structural engineer, the University's determination of the matter shall be final and conclusive on the Subcontractor. The cost of required engineering services shall be borne by the Subcontractor and shall be deemed to have been included in the amount bid for the work as stated in the Agreement.

Neither the review nor approval of any plan showing the design of scaffolding, bracing, attachment to the structure, or other provisions for worker protection shall relieve the Subcontractor from the obligation to comply with CCR Title 8 and CBSC for the design and construction of such protective work, and the Subcontractor shall indemnify the University from any and all claims, liability, costs, actions, and causes of action arising out of or related to the failure of such protective systems. The Subcontractor shall defend the University, its officers, employees, and agents in any litigation or proceeding brought with respect to the failure of such protective systems.

4. All contractors/subcontractors are responsible to instruct their employees in the safety significance, purpose, and use of the scaffolding safety procedures, and lift operation and maintain a record thereof. Training records for contractors/ 
subcontractors employees shall be delivered to Construction Management for filing.

5. All contractors/subcontractors are responsible for advising all other affected persons when their safety will be impacted by scaffolding.

6. All contractors/subcontractors must conduct daily inspections of scaffolding under their control to ensure that the requirements of the scaffolding safety program are being followed. Scaffolding shall be inspected by a designated competent person. Inspection documentation shall be delivered to Construction Management for filing.

University Employees and non-LLNL Employees (reference Section I.A.14 for definitions)

1. All LLNL employees and non-LLNL employees (including contract labor, supplemental labor, vendors, personnel matrixed/assigned from other National Laboratories, participating guests, visitors and students) at a minimum shall comply with the LLNL scaffolding and lift safety policy.

\section{Exceptions}

Requests by NIF Construction Contractors/Subcontractors for exceptions/modifications to LLNL scaffolding and lift safety requirements will only be approved if equivalent safety is demonstrated and OSHA requirements are met. Approvals shall be issued in writing by the cognizant Construction Manager (or Deputy Associate Project Engineer for Construction) with concurrence from LLNL's Safety Representative for the NIF project.

\section{Basic Rules for Scaffolding and Lift Safety}

1. All scaffolding shall be erected, maintained, and disassembled by workers trained in the safe erection, maintenance, and disassembly of scaffolding. The scaffolding crew shall work under the direction of a trained, certified, and competent scaffolding supervisor.

2. All manufactured scaffolding shall be erected and used in accordance with the manufacturer's instructions.

3. All platforms 6 feet or higher above the ground or surrounding surface shall be provided with standard guardrails, including top rail and midrail, on all open sides. Toeboards are required where necessary.

4. Midrails shall be located approximately midway between the top rail and the walking surface. Cross bracing can be used in place of midrails provided the cross meets at approximately the midheight between the top rail and the working surface. Cross bracing can be used in place of top rails provided the cross meets at approximately the height of the top rail and a separate midrail is also provided. 
5. Portable ladders shall be used to provide safe means of access to scaffolds where ladders are not an integral part of the scaffolding framework.

6. Integral scaffold stairways shall be employed when scaffolds exceed three stories tall. Stairways shall be provided with standard handrails.

7. Workers shall not ride on scaffolds when they are being moved unless the scaffold is on a level surface (within $3^{\circ}$ of level) and the base width of the scaffold is at least $1 / 2$ the height.

8. Scaffolds shall be level and plumb, and placed on adequate support. Plywood alone does not meet the support requirements. Metal base plates or wheels must be used on metal tubular or welded frame scaffolds. Castor wheels must be locked when the scaffold is not being moved.

9. A minimum of two scaffold grade planks shall be used to form a deck or walking surface. Manufactured scaffold planks must be used in accordance with manufacturer's instructions. All deck planking shall be secured to prevent movement.

10. Placing planks between ladders, or on top of buckets shall not be used in place of approved scaffolding. Heavy, industrial type saw horses capable of supporting planking, worker, and materials can be used to create scaffolding. Do not place saw horses on top of each other to gain a higher platform.

11. In order to prevent movement or tip over, scaffolding must be secured to the structure every 26 feet vertically and every 30 feet horizontally.

12. Scaffolds shall be maintained in a safe condition. Loose or missing guardrails, cracked or broken planks, structure out of plumb or level, unsupported bases, wheels unlocked, etc. make a scaffold unsafe. The scaffolding should not be used until unsafe conditions are corrected.

13. Do not overload a scaffold with materials or workers. Do not stand or climb on the guardrails. Portable ladders are not safe when used on top of scaffolds. Use of ladders on scaffolds must be reviewed and approved by a safety representative.

14. Scaffolds must be inspected daily and prior to use. Do not work on slippery scaffolding until it is cleared or sanded.

15. For other types of scaffolds such as mason's or bricklayer's scaffolds, see OSHA requirements.

16. Makeshift scaffolds are not permitted.

17. Scissor lift scaffolds must be used on level surfaces. Workers are permitted to remain on the lift when it is moved, provided the lift is lowered prior to being moved. Do not over load scissor lifts. Close all guardrails, gates, etc., at all times.

18. Articulating or extensible boom lifts shall be operated on level surfaces as much as possible and within guidelines established by the manufacturer. A full body harness must be worn by all occupants in the bucket or lift with a safety lanyard securely attached to the boom or bucket. Do not overload the lift. Lower the lift or retract the boom when moving to a new location when possible. 
19. Powered lifts such as scissors, articulating, or extensible boom lifts shall only be operated by workers trained to operate these devices.

20. Gasoline, diesel, or propane powered lifts shall only be operated in areas with adequate ventilation to prevent the buildup of carbon monoxide or other hazardous gases. When these lifts are operated indoors, air monitoring is required.

21. All elevated platforms higher than 25 feet must have a 25 foot clear zone around the perimeter of the work platform. The only personnel allowed in the clear zone will be personnel loading or unloading materials or equipment from the platform. Platforms larger than 100 square feet must be screened around the perimeter to prevent falling objects. 


\section{Machinery, Vehicles, and Heavy Equipment}

Operation and maintenance of machinery, vehicles, and heavy equipment such as earth movers, road graders, bulldozers, and large dump trucks can lead to serious injury to personnel. The operation and maintenance of all machinery, vehicles, and heavy equipment shall be based upon LLNL safety requirements, Federal OSHA, and California OSHA.

\section{Responsibilities}

NIF Construction Contractors/Subcontractors

1. All contractors/subcontractors must establish a heavy equipment safety program to ensure compliance with LLNL requirements, Federal OSHA, and California OSHA.

2. All contractors/subcontractors are responsible to develop, document, and utilize heavy equipment safety procedures as required.

3. All contractors/subcontractors are responsible for advising all other affected persons when their safety will be impacted by the operation and maintenance of heavy equipment.

4. All contractors/subcontractors are responsible for assuring that employees assigned to operate machinery, vehicles, or heavy equipment are trained, qualified, and licensed (where necessary) to operate the assigned machine, vehicle, or heavy equipment.

University Employees and non-LLNL Employees (reference Section I.A.14 for definitions)

1. All LLNL employees and non-LLNL employees (including contract labor, supplemental labor, vendors, personnel matrixed/assigned from other National Laboratories, participating guests, visitors and students) at a minimum shall comply with LLNL safety requirements.

\section{Exceptions}

Requests by NIF Construction Contractors/Subcontractors for exceptions/modifications to LLNL machinery, vehicle, and heavy equipment safety requirements will only be approved if equivalent safety is demonstrated and OSHA requirements are met. Approvals shall be issued in writing by the cognizant Construction Manager (or Deputy Associate Project Engineer for Construction) with concurrence from LLNL's Safety Representative for the NIF project. 


\section{Basic Rules For Machinery, Vehicles, And Heavy Equipment}

1. Unless it is part of their regular duties, for which they have had adequate training, no employees shall operate machinery or equipment without specific instructions and guidance. Only licensed operators shall operate vehicles. Motor vehicle operators must hold a current and valid operator's license for the type of vehicle to be operated.

2. No vehicle or heavy equipment shall be operated in a reckless or careless manner or at a speed that is not reasonable and proper with regard to weather, traffic, surface condition, visibility condition, load, or type of vehicle. Reckless operation may be grounds for removal of privilege to operate and possible disciplinary action.

3. Operators shall inspect vehicles and equipment daily before beginning work and at the end of the shift, reporting any obvious areas of possible malfunction (such as brakes or tires, leaking fuel or oil). Repairs shall be made promptly. Defective vehicles and equipment shall not be used until repairs are made. Job superintendents shall make daily safety inspections. Operators are responsible for immediately reporting to supervisors any apparent or latent unsafe conditions of the equipment being operated. Job site records shall be maintained, as required.

4. Motors of all equipment shall be shut off while being refueled.

5. Seat belts must be worn by operators and passengers when provided.

6. Back up alarms must be used on all equipment with an obstructed view to the rear. A signal person should be used to help guide backing equipment where necessary for safer backing, and when a back up alarm does not exist or is non functional. Do not disconnect back up alarms.

7. Heavy equipment can be difficult to maneuver in congested areas and may be slow in stopping or turning. Avoid right-of-way situations by always yielding to the heavy equipment. Heavy equipment operators must obey normal traffic right-of-way regulations. Site-specific heavy equipment traffic flow patterns may be established when necessary.

8. Flagpersons must wear high visibility orange vests or reflective clothing.

9. Persons on the ground working near where heavy equipment is being operated must remain in view of the operator. Do not walk or pass close in front of or behind heavy equipment. Never attempt to pass under heavy equipment.

10. Operators must not jump from their equipment - use ladders and steps provided.

11. Dump truck operators must exit their truck or remain in the protected cab if safe to do so when being loaded.

12. Stay clear of pinch points on heavy equipment such as where equipment articulates or where hydraulic arms move in or out. Pinch points must be guarded. 
13. Heavy equipment must not be operated on side slopes or inclines that present a danger of rolling over. Keep equipment away from the edge of banks of excavations and trenches that may collapse.

14. Outriggers must be used when operating equipment so provided such as rubbertired backhoes.

15. Backhoes shall not swing their buckets or loads over workers in trenches or excavations. Special care must be observed by operators and workers when moving trench shields.

16. Floors and decks of equipment shall be kept clean and free of anything that might cause slipping, tripping, or a falling hazard.

17. The need for servicing or repairs shall be reported to the supervisor. No repairs or adjustments shall be made on units during operation. No lubrication shall be performed on units during operation except those on which the manufacturer has installed safeguards specifically for the protection of the person doing the lubrication.

18. Working under suspended loads is forbidden.

19. Employees are prohibited from riding booms, loads, slings, hooks, or lift-truck forks or platforms.

20. Air hoses shall not be disconnected until they are bled and pressure is securely turned off at its source. All air hoses shall meet the requirements of 29 CFR 1926.302(b) (Federal OSHA Construction Safety Standards).

21. Employees shall inspect all backfill areas before starting backfill operations.

22. Caution shall be taken to make sure that no one is below when equipment is used near tops of cuts, banks, or inclines.

23. Special care, and an observer(s) with whom effective communication has been set up, shall be used where there is a possibility of overturning equipment (e.g., near tops of cuts, banks, inclines, deep fills, and soft or muddy terrain).

24. Adequate devices shall be worn for protection of hearing by operators or employees working near units producing noise levels in excess of prescribed standards.

25. Riding on flatbed trucks or in the back of pickups is not permitted. Riding on equipment is not permitted unless the vehicle is so equipped to safely carry passengers.

26. All vehicular accidents that occur on the Laboratory site, of whatever size and nature, whether injury or noninjury, shall be reported immediately to the superintendent and to the NIF Construction Manager. 


\section{Welding and Cutting-General}

The control of all welding and cutting shall be based upon LLNL safety requirements, Federal OSHA, and California OSHA.

\section{Responsibilities}

NIF Construction Contractors/Subcontractors

1. All contractors/subcontractors must establish a welding and cutting safety program to ensure compliance with LLNL requirements, Federal OSHA, and California OSHA.

2. All contractors/subcontractors are responsible to develop, document, and utilize welding and cutting safety procedures as required.

3. All contractors/subcontractors are responsible to instruct their employees in the safety significance, purpose, and use of welding and cutting safety procedures and maintain a record thereof. Training records for contractors/subcontractors employees shall be delivered to Construction Management for filing.

4. All contractors/subcontractors are responsible for advising all other affected persons when their safety will be impacted by welding and cutting.

University Employees and non-LLNL Employees (reference Section I.A.14 for definitions)

1. All LLNL employees and non-LLNL employees (including contract labor, supplemental labor, vendors, personnel matrixed/assigned from other National Laboratories, participating guests, visitors and students) at a minimum shall comply with the LLNL welding and cutting safety policy.

\section{Exceptions}

Requests by NIF Construction Contractors/Subcontractors for exceptions/modifications to LLNL welding and cutting safety requirements will only be approved if equivalent safety is demonstrated and OSHA requirements are met. Approvals shall be issued in writing by the cognizant Construction Manager (or Deputy Associate Project Engineer for Construction) with concurrence from LLNL's Safety Representative for the NIF project.

\section{Basic Rules for Welding and Cutting Safety}

1. Only trained employees, whose regular duties as assigned by their supervisors include welding and cutting, shall perform this work.

2. Only standard, approved equipment shall be used. 
3. Fire extinguishers will be easily accessible to all employees performing welding or cutting operations.

4. Screens or shields shall be provided for the protection of persons or combustible material exposed to sparks or falling objects; a fire-watch shall be posted where necessary, with an adequate extinguisher and signaling device.

5. When working on lead, zinc, or other materials that could generate harmful fumes, adequate ventilation and exhaust devices shall be provided. When ventilation is not practical or feasible, respiratory protection shall be used.

6. The designated safety representative or foreman shall inspect the work site before any use of welding or cutting equipment to ensure that all combustibles in the work area have been removed or otherwise protected from the welding or cutting work. He/she shall also assure that a current Hazardous Work Permit for hot work is in effect at the designated job site. 


\section{ARC Welding}

The control of arc welding shall be based upon LLNL safety requirements, Federal OSHA, and California OSHA.

\section{Responsibilities}

NIF Construction Contractors/Subcontractors

1. All contractors/subcontractors must establish an arc welding safety program to ensure compliance with LLNL requirements, Federal OSHA, and California OSHA.

2. All contractors/subcontractors are responsible to develop, document, and utilize arc welding safety procedures as required.

3. All contractors/subcontractors are responsible to instruct their employees in the safety significance, purpose, and use of arc welding safety procedures and maintain a record thereof. Training records for contractors/subcontractors employees shall be delivered to Construction Management for filing.

4. All contractors/subcontractors are responsible for advising all other affected persons when their safety will be impacted by arc welding.

University Employees and non-LLNL Employees (reference Section I.A.14 for definitions)

1. All LLNL employees and non-LLNL employees (including contract labor, supplemental labor, vendors, personnel matrixed/assigned from other National Laboratories, participating guests, visitors and students) at a minimum shall comply with the LLNL arc welding safety policy.

\section{Exceptions}

Requests by NIF Construction Contractors/Subcontractors for exceptions/modifications to LLNL arc welding safety requirements will only be approved if equivalent safety is demonstrated and OSHA requirements are met. Approvals shall be issued in writing by the cognizant Construction Manager (or Deputy Associate Project Engineer for Construction) with concurrence from LLNL's Safety Representative for the NIF project.

\section{Basic Rules for Welding and Cutting Safety}

1. Frames of welding machines operated from electric power sources shall be properly grounded.

2. When welding, employees shall wear adequate masks or hoods with proper eye protection, gloves, and leather aprons as minimum protection; these shall be 
supplemented with hard hats, safety shoes, and other protective gear where warranted.

3. All employees and passersby near the welding area shall be protected from eye flash-burns by use of partitions, screens, or other appropriate methods.

4. Welding cables, cords, and leads shall be neatly secured so as not to cause tripping.

5. Electrode stubs shall be disposed of immediately in a safe container. 


\section{Oxygen/Acetylene Welding and Cutting}

The control of all oxygen/acetylene welding and cutting shall be based upon LLNL safety requirements, Federal OSHA, and California OSHA.

\section{Responsibilities}

NIF Construction Contractors/Subcontractors

1. All contractors/subcontractors must establish an oxygen/acetylene welding and cutting safety program to ensure compliance with LLNL requirements, Federal OSHA, and California OSHA.

2. All contractors/subcontractors are responsible to develop, document, and utilize oxygen/acetylene welding and cutting safety procedures as required.

3. All contractors/subcontractors are responsible to instruct their employees in the safety significance, purpose, and use of oxygen/acetylene welding and cutting safety procedures and maintain a record thereof. Training records for contractors/subcontractors employees shall be delivered to Construction Management for filing.

4. All contractors/subcontractors are responsible for advising all other affected persons when their safety will be impacted by oxygen/acetylene welding and cutting.

University Employees and non-LLNL Employees (reference Section I.A.14 for definitions)

1. All LLNL employees and non-LLNL employees (including contract labor, supplemental labor, vendors, personnel matrixed/assigned from other National Laboratories, participating guests, visitors and students) at a minimum shall comply with the LLNL oxygen/acetylene welding and cutting safety policy.

\section{Exceptions}

Requests by NIF Construction Contractors/Subcontractors for exceptions/modifications to LLNL oxygen/acetylene welding and cutting safety requirements will only be approved if equivalent safety is demonstrated and OSHA requirements are met. Approvals shall be issued in writing by the cognizant Construction Manager (or Deputy Associate Project Engineer for Construction) with concurrence from LLNL's Safety Representative for the NIF project.

\section{Basic Rules for Oxygen/Acetylene Welding and Cutting}

1. Oxygen-Acetylene Welding and Cutting

2. Cylinders shall never be dropped or struck. 
3. Cylinders shall be stored away from any source of heat.

4. Where stored in the open, cylinders shall be protected from continuous sunlight.

5 Oxygen cylinders shall be stored at least $20 \mathrm{ft}$ away from those containing any fuel gas.

6. Where stored inside, oxygen cylinders shall be separated from those containing fuel gases by a 5-ft-high, noncombustible barrier with a fire rating of at least 0.5 $\mathrm{hr}$, or they shall be separated by a 20 -ft distance.

7. Cylinders shall be stored vertically and chained to prevent them from falling over.

8. Cylinders shall never be lifted by machinery unless they are in a safe stand or cradle or are otherwise positively secured against falling or being dropped.

9. Special arrangements shall be made to secure cylinders while they are being transported. Carrying them loose on the back of a truck or in a pickup is prohibited.

10. Caps shall be firmly screwed onto cylinders except when the cylinders are connected to a regulator during use.

11. Oxygen cylinders shall be kept free from oil or grease. Use of oil or grease as a lubricant for oxygen valves or attachments is prohibited.

12. Smoking or flame is prohibited near welding gas cylinders or outlets.

13. Field adjustment or repair of gauges, valves, accessories, or safety devices is prohibited.

14. Acetylene shall not be used for welding or cutting at pressures exceeding 15 psig.

15. Acetylene cylinder valves shall not be opened more than one full turn, and the wrench shall be left on the valve stem so that the valve can be closed quickly if necessary.

16. Oxygen cylinder valves shall be opened fully and made hand-tight against the back seat. This takes the high-range cylinder pressure off the packing.

17. Mixing gases in cylinders, refilling cylinders, or using cylinders for any use except their original purpose is prohibited.

18. It is permissible to close torch valves alone only when work is briefly suspended and the operator is nearby. Any other interruption of use (e.g., if one cylinder becomes empty) necessitates closing the cylinder valves, followed promptly by opening the torch valves to purge lead-hoses and releasing the regulator screws.

19. Hoses shall never be hung from regulators, other equipment, or the cylinder tops.

20. Reverse-flow check valves or flashback arrestors shall be provided on oxygen and acetylene systems. 


\section{Excavation, Trenching, and Shoring}

All excavations, including trenches shall be protected to prevent cave-in or loose soil falling into excavations through shoring, bracing, sheet piling, underpinning, sloping, or other methods. The control of all excavations shall be based upon LLNL excavation safety requirements, Federal OSHA, and California OSHA.

\section{Responsibilities}

NIF Construction Contractors/Subcontractors

1. All contractors/subcontractors must establish an excavation safety program to ensure compliance with LLNL requirements, Federal OSHA, and California OSHA.

2. All contractors/subcontractors are responsible to develop, document, and utilize excavation safety procedures as required.

3. Before beginning any excavation or trench that is 5 feet deep or more, the subcontractor shall submit to the Construction Manager for review and approval a detailed written plan showing the design of shoring, bracing, sloping, or other provisions to be made to protect workers from the hazard of caving ground during the excavation. The proposed plan shall comply with the standards established by State of California, CCR Title 8, and California Building Standards Code (CBSC)(formerly CCR Title 24). If the detailed plan varies from such shoring system standards, it shall be prepared by a California registered civil or structural engineer whose name and registration number shall be indicated on the drawings. If a dispute arises as to whether the plan shall be prepared by a registered civil or structural engineer, the University's determination of the matter shall be final and conclusive on the Subcontractor. The cost of required engineering services shall be borne by the Subcontractor and shall be deemed to have been included in the amount bid for the work as stated in the Agreement.

Neither the review nor approval of any plan showing the design of shoring, bracing, sloping, or other provisions for worker protection shall relieve the Subcontractor from the obligation to comply with CCR Title 8 and CBSC for the design and construction of such protective work, and the Subcontractor shall indemnify the University from any and all claims, liability, costs, actions, and causes of action arising out of or related to the failure of such protective systems. The Subcontractor shall defend the University, its officers, employees, and agents in any litigation or proceeding brought with respect to the failure of such protective systems.

4. All contractors/subcontractors are responsible to instruct their employees in the safety significance, purpose, and use of the excavation safety procedures, and maintain a record thereof. Training records for contractors/subcontractors employees shall be delivered to Construction Management for filing.

$$
\text { A-xlvii }
$$


5. All contractors/subcontractors are responsible for advising all other affected persons when their safety will be impacted by excavations.

6. All contractors/subcontractors must conduct daily inspections of excavations under their control to ensure that the requirements of the excavation safety program are being followed. Excavations shall be inspected by a designated competent person. Inspection documentation shall be delivered to Construction Management for filing.

University Employees and non-LLNL Employees (reference Section I.A.14 for definitions)

1. All LLNL employees and non-LLNL employees (including contract labor, supplemental labor, vendors, personnel matrixed/assigned from other National Laboratories, participating guests, visitors and students) at a minimum shall comply with the LLNL Excavation Safety Program.

\section{Exceptions}

Requests by NIF Construction Contractors/Subcontractors for exceptions/modifications to LLNL excavation safety requirements will only be approved if equivalent safety is demonstrated and OSHA requirements are met. Approvals shall be issued in writing by the cognizant Construction Manager (or Deputy Associate Project Engineer for Construction) with concurrence from LLNL's Safety Representative for the NIF project.

\section{Basic Rules for the Excavation Safety Program}

1. Workers shall not enter or work in any excavation which has not been properly shored, sloped, shielded or otherwise protected from cave-in.

2. All excavations shall be under the control of a competent person who is both capable of identifying existing and predictable excavation hazards, and authorized to take prompt corrective measures to eliminate them. The competent person shall make daily inspections of excavations and the adjacent areas. Excavations shall be inspected by the competent person prior to work and as often as needed throughout the work shift. Inspections shall also be made after rainstorms.

3. All shoring shall be installed, maintained, and removed only by workers trained to install the shoring system being employed. Hydraulic shoring shall be installed in accordance with the OSHA tables, and the manufacturer's data and recommendations.

4. Prior to excavation, attempts must be made to locate underground utilities. Refer to contract requirements for locating buried utilities.

5. Suitable temporary barricades, fences, or other structures as required for the protection of public traffic and employees shall be provided around excavations. Barricading of excavations and trenches shall conform to LLNL standards. 
Lighted barricades must be used on all roadways. Excavations in remote locations shall be barricaded. Refer to the contract for barricading requirements.

6. All personnel bridges over trenches or excavations 2 feet or more wide must be equipped with standard safety railing. Workers shall not attempt to jump across excavations or trenches.

7. Excavations may be considered confined work spaces and shall initially be treated as such when access is necessary. Refer to Section 7 Confined Space Safety Precautions regarding entry into excavations.

8. Excavation spoil piles shall be located sufficiently far away from the excavation so that the toe of the pile of excavated material is at least 2 feet from the edge of the excavation.

9. A safe means of access including ladders, stairs, steps, ramps, etc., shall be provided for all excavations 4 feet or greater in depth. Ladders shall not be located further than 25 feet from workers in an a trench or excavation unless other means of access are provided.

10. When working in excavations, workers shall stay within the protected areas of the excavation (e.g. stay within the shoring, trench shield, etc.).

11. Workers must keep alert for changing ground conditions or signs of possible movement. If any unsafe excavation conditions are found, exit the excavation immediately and report the conditions to your supervisor and to the designated competent person. Do not allow others to enter the excavation until unsafe conditions have been corrected.

12. Heavy equipment shall not be allowed to work near the edge of excavations where personnel in the excavation would be at risk from the equipment toppling into the excavation. Stop logs, barricades, or berms shall be used to prevent heavy equipment from rolling into excavations.

13. SARA/OSHA training is required for employees handling contaminated soil. 


\section{Fall Protection}

All fall protection shall be used and maintained in a safe manner to prevent injury to workers. The use of fall protection shall be based upon LLNL fall protection safety requirements, Federal OSHA, and California OSHA.

\section{Responsibilities}

\section{NIF Construction Contractors/Subcontractors}

1. All contractors/subcontractors must establish a fall protection safety program to ensure compliance with LLNL requirements, Federal OSHA, and California OSHA.

2. All contractors/subcontractors are responsible to develop, document, and utilize fall protection equipment and safety procedures as required.

3. All contractors/subcontractors are responsible to instruct their employees who may be exposed to fall hazards in the safety significance, purpose, and use of fall protection equipment and procedures, and maintain a record thereof. Training records for contractors/subcontractors employees shall be delivered to Construction Management for filing.

4. All contractors/subcontractors must conduct inspections of fall protection equipment under their control to ensure that the requirements of the fall protection safety program are being followed. Fall protective equipment such as body harnesses, positioning belts, lanyards, safety lines, special rope grabs, retractable lifelines and reels, etc., must be inspected at least every six months and documented on an inspection tag affixed to the equipment. Inspection documentation shall be delivered to Construction Management for filing.

University Employees and non-LLNL Employees (reference Section I.A.14 for definitions)

1. All LLNL employees and non-LLNL employees (including contract labor, supplemental labor, vendors, personnel matrixed/assigned from other National Laboratories, participating guests, visitors and students) at a minimum shall comply with the LLNL fall protection program requirements.

\section{Exceptions}

Requests by NIF Construction Contractors/Subcontractors for exceptions/modifications to LLNL fall protection safety requirements will only be approved if equivalent safety is demonstrated and OSHA requirements are met. Approvals shall be issued in writing by the cognizant Construction Manager (or Deputy Associate Project Engineer for Construction) with concurrence from LLNL's Safety Representative for the NIF project. 


\section{Basic Rules for Fall Protection}

1. Workers shall be protected against falling whenever a fall hazard exists.

2. Fall protection is required on all open sides and edges of walking/working surfaces with an unprotected side or edge which is 6 feet $(1.8 \mathrm{~m})$ or more above a lower level. Fall protection is also required when workers are exposed to a fall of 6 feet or more near holes (including skylights), shafts, pits, excavations, ramps, runways, above dangerous equipment, wall openings (where the bottom edge of the opening is less than 39 inches above the walking surface), on formwork and reinforcing steel, overhand bricklaying, precast concrete erection, and roof work.

3. Fall protection shall be provided by use of guardrail systems, safety net systems, or personal fall arrest systems.

4. Holes (including skylights) shall be protected by covers or guardrails. Floor hole covers shall be marked with the word "HOLE" or "COVER." Covers shall be strong enough to support the intended load, and shall be secured to prevent accidental displacement.

5. Standard guardrails shall be installed in accordance with OSHA requirements. Toeboards or screens are required when necessary to protect against falling objects.

6. Only full body harnesses are permitted, and they shall be used with a shock absorbing lanyard. Body belts are not allowed except when sued as a positioning device. A chain lanyard may be used with a body belt for positioning use only.

7. Each employee shall also wear a safety harness with a safety lanyard secured to a separate lifeline while working from swing scaffolds, bos'n chairs or other suspended work platforms where a falling hazard is present.

8. The project will be a $100 \%$ tie off project, requiring the use of two lanyards when exposed to a fall greater than six (6) feet.

9. Safety nets shall be provided when work places are more than 25 feet above the ground or other surfaces where the use of ladders, scaffolds, catch platforms, temporary floors, safety lines or safety harnesses use is impossible. 


\section{Steel Erection}

Steel erection is recognized as an inherently hazardous construction activity. All steel erection shall be conducted in a safe manner to prevent injury to workers. The control of all steel erection shall be based upon LLNL steel erection safety requirements, Federal OSHA, and California OSHA.

\section{Responsibilities}

NIF Construction Contractors/Subcontractors

1. All contractors/subcontractors must establish a steel erection safety program to ensure compliance with LLNL requirements, Federal OSHA, and California OSHA.

2. All contractors/subcontractors are responsible to develop, document, and utilize steel erection safety procedures as required.

3. All contractors/subcontractors are responsible to instruct their employees in the safety significance, purpose, and use of the steel erection safety procedures, and maintain a record thereof. Training records for contractors/subcontractors employees shall be delivered to Construction Management for filing.

University Employees and non-LLNL Employees (reference Section I.A.14 for definitions)

1. All LLNL employees and non-LLNL employees (including contract labor, supplemental labor, vendors, personnel matrixed/assigned from other National Laboratories, participating guests, visitors and students) at a minimum shall comply with LLNL steel erection requirements.

\section{Exceptions}

Requests by NIF Construction Contractors/Subcontractors for exceptions/modifications to LLNL steel erection safety requirements will only be approved if equivalent safety is demonstrated and OSHA requirements are met. Approvals shall be issued in writing by the cognizant Construction Manager (or Deputy Associate Project Engineer for Construction) with concurrence from LLNL's Safety Representative for the NIF project.

\section{Basic Rules for Steel Erection}

1. Fall protection shall be provided to workers when they are exposed to a fall hazard of 6 feet or more. Fall protection shall meet the requirements of Section 16 and OSHA Steel Erection requirements. 
2. Workers are not permitted to walk on top of structural steel at any time without having fall protection. Straddling and walking on the side flanges also requires fall protection.

3. Ladders, scaffolds, lifts, etc., shall be used to reach elevated locations. Climbing or sliding down structural steel from one level to another is not permitted.

4. Welders and other workers who are performing stationary work shall use fall protection attached to a secure anchorage.

5. When placing solid web structural steel members, the load shall not be released from a hoisting line until the members are secured with not less than two bolts at each connection and drawn up wrench tight.

6. When placing open web steel joists on structural steel framework, or placing loads on open web steel joists, the structural framework and open web steel joists shall be safely bolted together.

7. Structural steel framework shall be temporarily guyed or braced to prevent collapse.

8. Bolts, drift pins, tools, etc., shall be secured against falling. Air hose connections shall be restrained.

9. "Christmas-treeing" of structural steel shall not be allowed.

10. Tag lines shall be used to control loads.

11. When wire rope is used as a floor periphery-safety railing, the wire rope shall be $1 / 2$-inch diameter, installed approximately 42 inches high, and flagged at not more than 6-foot intervals. A minimum of 3 each drop-forged wire rope clips shall be used at each connection point or splice. 


\section{Working With Asbestos}

All work with asbestos shall be conducted in accordance with the provisions of 8 CCR, 29 CFR 1926.58, the asbestos safety criteria subcontract specifications, and Supplement 21.19 of LLNL Health $\mathcal{E}$ Safety Manual (available through the construction manager or Program construction coordinator). All asbestos-related work shall be performed only by personnel/employees who have received appropriate mandated by CAL/OSHA. These rules apply to the NIF construction site and adjacent areas of LLNL.

\section{Responsibilities}

NIF Construction Contractors/Subcontractors

All Construction Contractors/Subcontractors employees shall comply with LLNL requirements.

University Employees and non-LLNL Employees (reference Section I.A.14 for definitions)

1. All LLNL employees and non-LLNL employees (including contract labor, supplemental labor, vendors, personnel matrixed/assigned from other National Laboratories, participating guests, visitors and students) at a minimum shall comply with the LLNL Environment, Safety, and Health Program and applicable requirements of the NIF Construction Safety Program.

\section{Exceptions}

Requests by NIF Construction Contractors/Subcontractors for exceptions/ modifications to LLNL safety requirements will only be approved if equivalent safety is demonstrated and OSHA requirements are met. Approvals shall be issued in writing by the cognizant Construction Manager (or Deputy Associate Project Engineer for Construction) with concurrence from LLNL's Safety Representative for the NIF project. 


\section{Radiation Safety}

All use of radioactive materials, ionizing radiation sources, or radiographic equipment shall comply with 29 CFR 1910.96, 10 CFR 20, 10 CFR 835, 17 CCR, and the LLNL Health \& Safety, Environmental Compliance, and Radiological Control Manuals. The construction manager or construction coordinator shall be notified before the start of work with radioactive materials, ionizing radiation sources, or radiographic equipment, or when work will occur in areas where access is controlled for radiation safety purposes.

Before the start of a job involving a radioactive materials, ionizing radiation sources, or radiographic equipment the construction manager or construction coordinator shall notify the Construction Safety Officer who will alert the cognizant ES\&H Team 2 Health Physicist.

When radiation dosimeters are issued to contract/subcontract personnel, they shall be exchanged at least on a quarterly basis (monthly, if required) and turned in at the completion of the assignment.

\section{Responsibilities}

NIF Construction Contractors/Subcontractors

All Construction Contractors/Subcontractors employees shall comply with LLNL requirements.

University Employees and non-LLNL Employees (reference Section I.A.14 for definitions)

1. All LLNL employees and non-LLNL employees (including contract labor, supplemental labor, vendors, personnel matrixed/assigned from other National Laboratories, participating guests, visitors and students) at a minimum shall comply with the LLNL Environment, Safety, and Health Program and applicable requirements of the NIF Construction Safety Program.

\section{Exceptions}

Requests by NIF Construction Contractors/Subcontractors for exceptions/modifications to LLNL safety requirements will only be approved if equivalent safety is demonstrated and OSHA requirements are met. Approvals shall be issued in writing by the cognizant Construction Manager (or Deputy Associate Project Engineer for Construction) with concurrence from LLNL's Safety Representative for the NIF project. 


\section{Hand Tools}

All hand tools, whether self-owned or company-furnished, shall be maintained in safe condition and comply with the applicable Federal and California OSHA requirements. Unsafe tools shall not be used until repaired. Employees and personnel on the NIF construction site shall comply with the Basic NIF Construction Site Hands Tool Safety Rules

\section{Responsibilities}

NIF Construction Contractors/Subcontractors

1. All Construction Contractors/Subcontractors employees shall comply with LLNL requirements and the Basic NIF Construction Site Hands Tool Safety Rules.

University Employees and non-LLNL Employees (reference Section I.A.14 for definitions)

1. All LLNL employees and non-LLNL employees (including contract labor, supplemental labor, vendors, personnel matrixed/assigned from other National Laboratories, participating guests, visitors and students) at a minimum shall comply with the LLNL Environment, Safety, and Health Program and the Basic NIF Construction Site Hands Tool Safety Rules

\section{Exceptions}

Requests by NIF Construction Contractors/Subcontractors for exceptions/modifications to LLNL safety requirements will only be approved if equivalent safety is demonstrated and OSHA requirements are met. Approvals shall be issued in writing by the cognizant Construction Manager (or Deputy Associate Project Engineer for Construction) with concurrence from LLNL's Safety Representative for the NIF project.

\section{Basic NIF Construction Site Hand Tool Safety Rules}

a. Damaged or Defective Tools. Do not use broken, defective, burned or mushroomed tools. Report defective tools to your supervisor and turn tool in for replacement.

b. Hard Facing. Do not strike two hardened steel surfaces together; i.e., two hammers or a hammer and hardened steel shafts bearings, etc.

c. Power Tools. Only assigned, qualified operators will operate power, explosive actuated or air driven tools. 
d. Proper Tool. Always use the proper tool and equipment for any task you may be assigned to do. For example: do not use a wrench as a hammer or a screwdriver as a chisel.

e. Storage. Keep tools in their proper storage place when not in use. Do not leave tools where they might present a tripping hazard, fall on somebody or be stolen. Do not carry sharp edged tools in your pockets.

f. Securing. TOOLS THAT ARE EXPOSED TO A FALL FROM ONE LEVEL TO ANOTHER, SHALL BE TETHERED TO PREVENT INJURY TO PERSONNEL OR DAMAGE TO EQUIPMENT.

g. Guards. Guards required on power tools shall be used at all times. Switchlocking devices shall comply with the requirements of 29 CFR 1926.300. Power grinders shall have protective shields.

h. Refueling. All gasoline- or diesel-powered tools and equipment shall be stopped during refueling.

i. Powder-actuated. Studguns, powder-actuated, and powder-assisted industrial tools must be designed and equipped to prevent free flight of any projectile. Operators shall be trained and licensed by the tool's manufacturer in the operation of the particular tool in use and carry a valid operator's card for the specific tool. Records of training and certification will be maintained by the subcontractor. Tools are never to be left unattended, except when properly stored.

j. Appropriate personal protective equipment shall be used. 


\section{Electrical Safety}

Electricity when handled carelessly can lead to electrical shock, burns, or other serious injury or fatality. Electricity must be respected at all times. Worker exposure to electrical energy must be controlled. The control of electrical hazards shall be based upon LLNL electrical safety policy and requirements, Federal OSHA, and California OSHA.

\section{Responsibilities}

NIF Construction Contractors/Subcontractors

1. All contractors/subcontractors must establish an electrical safety program to ensure compliance with LLNL electrical safety policy and requirements, Federal OSHA, and California OSHA.

University Employees and non-LLNL Employees (reference Section I.A.14 for definitions)

1. All LLNL employees and non-LLNL employees (including contract labor, supplemental labor, vendors, personnel matrixed/assigned from other National Laboratories, participating guests, visitors and students) at a minimum shall comply with LLNL electrical safety policy and requirements.

\section{Exceptions}

Requests by NIF Construction Contractors/Subcontractors for exceptions/modifications to LLNL electrical safety requirements will only be approved if equivalent safety is demonstrated and OSHA requirements are met. Approvals shall be issued in writing by the cognizant Construction Manager (or Deputy Associate Project Engineer for Construction) with concurrence from LLNL's Safety Representative for the NIF project.

\section{Basic Rules for Electrical Safety}

1. Only trained, qualified, and authorized persons shall install wiring or perform work or repairs on electrical equipment.

2. Ground Fault Circuit Interrupter (GFCI) protection is required on all temporary 15-20-A, single-phase electrical power circuits. This applies both indoors and outdoors.

3. Electrical power equipment (tools, machines, extension cords, etc.) shall be maintained in safe working condition free of electrical hazards such as frayed cords, missing ground connector pins, loose or missing grounds, or electrical 
shorting. Defective equipment must be tagged out of use and removed from service immediately.

4. Electric tools shall be grounded using three-prong plugs and receptacles (except for double insulated tools). All electrical equipment must be properly grounded.

5. Temporary power cords (extension cords) shall only be used in continuous lengths, free of splices. Where spliced, splices shall have insulation equal to that of the cable. Cords shall be routed in areas away from vehicle and pedestrian traffic flow. Temporary power cords shall not be supported with or attached to the building structures with nails, wire, or by conductive materials. Cords must be elevated above wet areas or standing water.

6. Temporary lights shall be equipped with guards to prevent accidental breakage or contact with energized parts. Guards shall not be required when the reflectors are constructed with bulbs that are deeply recessed. Temporary lights shall be equipped with heavy-duty electrical cords, with connections and insulation maintained in safe condition. Temporary lights shall not be suspended by their electric cords unless the cords and lights are designed for such suspension. Temporary power must not be obtained by connecting to temporary lighting circuits.

7. Power distribution boxes, also known as "spider boxes," approved for use in construction, shall be used to supply temporary power. Temporary power taps, better known as multiple outlet boxes, surge protectors, etc. are not approved for use in construction and shall not be used.

8. Only "Approved" electrical equipment and wiring methods shall be used. Improvising is not allowed.

9. Wiring methods and practices shall follow the National Electrical Code and the National Electrical Safety Code.

10. For non electrical work performed in proximity to energized equipment, see Section 22.

11. Control all sources of electrical power at all times. This can be accomplished during testing by closing equipment covers, installing temporary covers of equivalent protection (no use of cardboard covers), use of barricades, insulating blankets, or by stationing a person to warn others of exposed electrical energy.

12. High Voltage equipment, insulating gloves, blankets, grounding equipment, etc. shall be maintained in safe condition and tested for electrical defects at least quarterly. Results of testing shall be recorded and the records kept on file.

13. Only qualified High Voltage Electricians shall perform work on energized High Voltage circuits or equipment.

14. Use only the test instruments and insulated tools rated for the voltage and current specified.

15. Wear appropriate personnel protective equipment (PPE).

16. IT IS LLNL POLICY TO WORK ON ELECTRICAL CIRCUITS AND EQUIPMENT IN A DE-ENERGIZED STATE USING THE LOCKOUT AND TAG PROCEDURE, 
except where working on energized equipment is safer than de-energizing it or where it is essential for the equipment to remain energized. Programmatic convenience is not sufficient cause to work on energized equipment. Approval is necessary prior to performing work on energized equipment. A special safety procedure may be required.

17. De-energize hazardous energy sources for the equipment or system. Lockout and tag all hazardous energy sources. Make sure that the controls will not operate the equipment or system and that all hazardous energy, including residual or stored energy is blocked, discharged, or relieved prior to starting work. Follow the Lockout and Tag Procedure, Section 24 when deenergizing any electrical power.

18. When handling acid or batteries, wear face shields and protective clothing such as rubber gloves and aprons. Immediately flush with water any acid coming into contact with your skin. Avoid breathing acid vapors.

19. Be alert to and strictly obey all warning and danger tags or signs around electrical apparatus. Do not close a switch that has a danger tag on it signed by or placed there by someone else. 


\section{Nonelectrical Work Performed Near Exposed High-Voltage Power- Distributed Equipment}

All nonelectrical work performed near exposed high-voltage (i.e., 600 volts or greater) power distribution equipment, including electrical lines, substations, switchyards, manholes/vaults, and other similar installations shall be in accordance with LLNL's guidelines (available through the cognizant NIF Construction Safety Officer). Included in the guidelines are activities such as wire pulling and splicing, excavating and trenching, boom/crane/manlift operations, fencing, lighting, drilling, and other construction work.

\section{Responsibilities}

NIF Construction Contractors/Subcontractors

1. All Construction Contractors/Subcontractors employees shall comply with LLNL requirements.

University Employees and non-LLNL Employees (reference Section I.A.14 for definitions)

1. All LLNL employees and non-LLNL employees (including contract labor, supplemental labor, vendors, personnel matrixed/assigned from other National Laboratories, participating guests, visitors and students) at a minimum shall comply with the LLNL Environment, Safety, and Health Program and the NIF Construction Safety Rules

\section{Exceptions}

Requests by NIF Construction Contractors/Subcontractors for exceptions/modifications to LLNL safety requirements will only be approved if equivalent safety is demonstrated and OSHA requirements are met. Approvals shall be issued in writing by the cognizant Construction Manager (or Deputy Associate Project Engineer for Construction) with concurrence from LLNL's Safety Representative for the NIF project. 
23. (Reserved)

A-lxii 


\section{Lockout/Tag Requirements}

The control of all energy sources that have been deenergized for the purpose of maintenance, repair, and / or modification shall be based upon the requirements of LLNL Health \& Safety Manual Supplement 26.13 ("LLNL Lockout and Tag Program"), Federal OSHA, and California OSHA.

A "zero energy" state shall be applied to all operations involving:

1. Water pressure.

2. Hot water in excessive of 120 degrees.

3. Fuel gasses (in pipelines or cylinders).

4. Compressed air.

5. Hydraulics.

6. Mechanical (stored energy).

7. Electrical Energy.

8. Steam

9. Gravity

\section{Responsibilities}

NIF Construction Contractors/Subcontractors

1. All contractors/subcontractors must establish an energy control program to ensure compliance with the LLNL Lockout and Tag Program, Federal OSHA, and California OSHA.

2. All contractors/subcontractors are responsible to develop, document, and utilize energy control procedures as required.

3. All contractors/subcontractors are responsible to instruct their employees in the safety significance, purpose, and use of the lockout/tagout procedures every six months and maintain a record thereof. Each new or transferred employee shall be instructed immediately upon assignment where this procedure may become a factor to the employee's safety. Training records for contractors/subcontractors employees shall be delivered to Construction Management for filing.

4. All contractors/subcontractors are responsible for advising all other affected persons when their safety will be impacted by an energy control action.

5. All contractors/subcontractors must conduct periodic inspections of the energy control procedure at least annually to ensure that the procedure and the requirements of the program are being followed. Inspection documentation shall be delivered to Construction Management for filing. 
University Employees and non-LLNL Employees (reference Section I.A.14 for definitions)

1. All LLNL employees and non-LLNL employees (including contract labor, supplemental labor, vendors, personnel matrixed/assigned from other National Laboratories, participating guests, visitors and students) at a minimum shall comply with the LLNL Lockout and Tag Program (Supplement 26.13).

\section{Exceptions}

Requests by NIF Construction Contractors/Subcontractors for exceptions/modifications to requirements in the LLNL Lockout and Tag Program will only be approved if equivalent safety is demonstrated and OSHA requirements are met. Approvals shall be issued in writing by the cognizant Construction Manager (or Deputy Associate Project Engineer for Construction) with concurrence from LLNL's Safety Representative for the NIF project.

\section{Basic Rules for the Use of Lockout/Tagout Procedures}

1. All equipment shall be locked and tagged out to protect against accidental or inadvertent operation when such operation could cause injury to personnel.

2. No one shall attempt to operate any switch or other energy isolating device when it is locked and tagged out.

3. Any unauthorized person found tampering with or removing lockout/tagout equipment will be subject to disciplinary actions as outlined in the Contractor's Program or under LLNL Policy.

4. Locks, lockout devices, and tags shall be standardized across the construction project in accordance with the LLNL Lockout and Tag Program.

5. An orderly transfer of lockout and tagout devices shall take place when personnel or shifts change as described in the LLNL Lockout and Tag Program. Control of energy sources that extends beyond a single shift or personnel change shall be logged in the NIF Project Lockout/Tagout Log Book maintained by Construction Management.

6. Group lockout and tag procedures shall be followed when maintenance, repair, and/or modification activities are performed by a crew, craft, different contractors, or other group. 


\section{Rigging}

All rigging shall be used and maintained in a safe manner to prevent injury to workers or dropping of loads. The control of all rigging shall be based upon LLNL safety requirements, Federal OSHA, and California OSHA.

\section{Responsibilities}

NIF Construction Contractors/Subcontractors

1. All contractors/subcontractors must establish a rigging safety program to ensure compliance with LLNL requirements, Federal OSHA, and California OSHA.

2. All contractors/subcontractors are responsible to develop, document, and rigging safety procedures as required.

3. All contractors/subcontractors are responsible to instruct their employees in the safety significance, purpose, selection and use of rigging, and rigging procedures, and maintain a record thereof. Training records for contractors/subcontractors employees shall be delivered to Construction Management for filing.

4. All contractors/subcontractors are responsible for advising all other affected persons when their safety will be impacted by cranes and hoists.

5. All contractors/subcontractors must conduct inspections of rigging under their control prior to use and quarterly to ensure that the requirements of the rigging safety program are being followed. Rigging shall be inspected by a designated competent person. Inspection documentation shall be delivered to Construction Management for filing.

University Employees and non-LLNL Employees (reference Section I.A.14 for definitions)

1. All LLNL employees and non-LLNL employees (including contract labor, supplemental labor, vendors, personnel matrixed/assigned from other National Laboratories, participating guests, visitors and students) at a minimum shall comply with the LLNL rigging safety requirements.

\section{Exceptions}

Requests by NIF Construction Contractors/Subcontractors for exceptions/ modifications to LLNL rigging safety requirements will only be approved if equivalent safety is demonstrated and OSHA requirements are met. Approvals shall be issued in writing by the cognizant Construction Manager (or Deputy Associate Project Engineer for Construction) with concurrence from LLNL's Safety Representative for the NIF project. 


\section{Basic Rules for Rigging Safety}

1. Rigging of loads shall be performed by workers trained, qualified, and authorized to perform such work.

2. Rigging shall be adequate to support the intended loads Special lifting devices, spreader bars, custom designed grabs, clamps, etc., shall be capable of handling the intended loads. These devices shall be marked to indicate safe working loads, and shall be proof-tested prior to use to 125 percent of their rated loads.

3. When temporary rigging such as wire rope lashing, come-alongs, chain falls, etc., are used for support during all erection sequences for machines, piping, platforms, walkways, and steel members such rigging shall not be removed until all leveling and alignment is complete and the item is secured in its permanent location.

4. Job or shop hooks formed from bolts, rods, rebar, etc., will not be used.

5. No "Christmas Treeing" shall be allowed on the construction project.

6. Rigging equipment will be inspected before each use, and as necessary during its use, to ensure that it is sound. All rigging equipment including, but not limited to, slings (wire and nylon), chain-falls, come-alongs, spreaders, lifting beams, etc., shall be inspected on a quarterly basis. Records will be maintained and copied to the Safety Coordinator. The inspection shall be performed by a competent person and the rigging equipment color coded in accordance with the suggested color code for the quarter.

7. Defective rigging shall be tagged "Do Not Use" and immediately removed from service and repaired or destroyed to prevent their reuse.

8. Proper storage shall be provided for slings and other rigging.

9. Protection shall be provided between the sling and any sharp, unyielding surfaces.

10. Reels of wire rope must not be dropped from a car or truck. To keep the wire rope clean and dry during storage, it should be coated with a protective material (LEPRO) to seal out air and moisture. Whether in storage or in use, all wire rope should be kept well lubricated. Wire rope will not be stored where it might be exposed to acid fumes or other corrosive agents.

11. To avoid kinks, the reel of wire rope must be mounted on jacks or a turntable to allow it to revolve as rope is pulled off. During installation, the rope should be made to turn the same direction off the reel as onto the drum to avoid reverse bends. During the break in period, the new rope should be run without a load. The first load should be gradually increased to set the wire.

12. Wire rope will be discarded when found to contain: Six randomly distributed broken wires in one rope lay, three broken wires in one strand of one rope lay, or when the rope shows signs of excessive wear, kinks, corrosion, or other defects. Wire ropes with splices will not have less than three tucks.

13. " $U$ " bolt wire rope clips shall be applied so that the " $U$ " section is in contact with the "dead end" of the rope. Only drop-forged " $U$ " bolts shall be used. 
14. Drums and sheaves shall be of the proper size to match the flexibility of the cable. Sheaves shall be of the proper size so as not to pinch the cable. The grooves of drums and sheaves should be kept smooth, free of burrs or defects. Sheaves, drums, and rollers should be properly aligned. Misalignment causes excessive wear to the cable and, over a period of time, may wear off an entire flange of sheaves. Overwinding and cross-winding should be avoided; either will abrade and distort the rope. Check the groove diameter of all sheaves with a "groove gauge." Using wire rope in an oversized sheave causes the rope to become flattened or distorted; using undersized grooves will pinch and tear the strands of wire. Check the sheaves and blocks for worn bearings. Allowing the sheaves to wobble on the pins will cause the wire rope to rub and wear the sides of the sheaves' throat. 


\section{Cranes}

All cranes and hoists shall be operated in a safe manner to prevent injury to workers, collapse or tip over, or damage to property. The control of all cranes and hoists shall be based upon LLNL safety requirements, Federal OSHA, and California OSHA.

\section{Responsibilities}

NIF Construction Contractors/Subcontractors

1. All contractors/subcontractors must establish a crane and hoist safety program to ensure compliance with LLNL requirements, Federal OSHA, and California OSHA.

2. All contractors/subcontractors are responsible to develop, document, and utilize crane and hoist safety procedures as required.

3. Before erecting any fixed or mobile tower crane, the contractor/subcontractor shall submit to the Construction Manager for review and approval a detailed written plan showing the tower crane design, bracing, nature and weight of anticipated loads, operating procedures, or other provisions to be made to protect workers from the hazard of tower crane collapse or tip over, a statement of current crane inspection certification, etc. The erection and operation of a fixed or mobile tower crane shall comply with the standards established by State of California, CCR Title 8.

4. Prior to set up and operation of all mobile cranes, the contractor/subcontractor shall present the crane for a safety inspection or review of current crane inspection certification by the Construction Manager or his representative. The contractor/subcontractor shall ensure and provide certification information as required by OSHA. Certification information shall verify that a thorough, annual inspection of the equipment has been made by a professional engineer or agency recognized by the governing body. Equipment owners are required by OSHA to maintain a record of the dates and results of inspections for each hosting machine and piece of equipment. Cranes found to be defective or not current in their annual inspection shall not be permitted to operate until all deficiencies have been corrected.

5. All contractors/subcontractors are responsible to instruct their employees in the safety significance, purpose, and use of crane and hoist safety procedures, and maintain a record thereof. Training records for contractors/subcontractors employees shall be delivered to Construction Management for filing.

6. All contractors/subcontractors are responsible for advising all other affected persons when their safety will be impacted by cranes and hoists.

7. All contractors/subcontractors must conduct daily inspections of cranes and hoists under their control to ensure that the requirements of the crane and hoist 
safety program are being followed. Cranes and hoists shall be inspected by a designated competent person. Inspection documentation shall be delivered to Construction Management for filing.

University Employees and non-LLNL Employees (reference Section I.A.14 for definitions)

1. All LLNL employees and non-LLNL employees (including contract labor, supplemental labor, vendors, personnel matrixed/assigned from other National Laboratories, participating guests, visitors and students) at a minimum shall comply with the LLNL crane and hoist safety requirements.

\section{Exceptions}

Requests by NIF Construction Contractors/Subcontractors for exceptions/modifications to LLNL crane and hoist safety requirements will only be approved if equivalent safety is demonstrated and OSHA requirements are met. Approvals shall be issued in writing by the cognizant Construction Manager (or Deputy Associate Project Engineer for Construction) with concurrence from LLNL's Safety Representative for the NIF project.

\section{Basic Rules for Crane and Hoist Safety}

1. Cranes and hoists shall be operated only by persons trained, qualified, and authorized to operate such equipment.

2. Cranes and hoists shall not be overloaded. Side pulls shall be avoided. Avoid sudden stops or starts which generate shock loading.

3. Loads shall not be passed or carried over workers. Employees shall not work beneath suspended loads until the load is safely blocked or landed.

4. Workers are not allowed to ride on loads, hooks, cables, load blocks, rigging etc.

5. All crane operation in proximity to electrical distribution and transmission lines shall be protected as outlined by OSHA requirements. A minimum separation distance of ten feet between the crane or load and an energized line is required at all times during operation.

6. Cranes shall be operated in accordance with the following requirements:

The Supervisor of the crane operator shall:

a. Ensure that assignment of any operator places someone experienced and qualified in conjunction with a particular piece of equipment.

b. Survey the specific area where the crane will be operating, making certain that all interfering conditions and factors are pointed out to the operator, and that appropriate preventive action is taken prior to the start of operation.

c. Provide adequate job instruction to the operator. 
d. Specifically instruct the operator that if any portion of the machine does not function properly, the machine is to be stopped, the Supervisor is to be contacted, and further instructions will be delivered.

e. Instruct the operator that he/she must be able to see the boom tip at all times. Be certain to keep height of rig below the limits established by the FAA.

f. Ensure proper operating and mechanical condition of the machine.

g. Exercise extremely good judgment about being present, and directly contributing to the handling of extremely heavy or difficult lifts.

h. Have the swing radius of the counterweight barricaded.

i. Keep two pairs of orange gloves or vests on the crane to be used by flagpersons to distinguish themselves from other personnel.

7. The Supervisor of personnel using the crane shall:

a. Survey the specific area in which the crane will be working making certain that all interfering conditions and factors are noted and that appropriate preventative action is planned and implemented before starting operation.

b. Give adequate job instructions to all personnel concerned (especially the crane operator).

c. Assign a flagperson (or more if required) who is knowledgeable about rigging practices, crane capacity and operating procedures to provide all signals to the crane operator.

d. Fully instruct the flagperson as to the planned use of the crane. (In all cases involving assignment of one flagperson or multiple flagpersons, ensure that each understands his/her responsibilities.)

e. Whenever there is any question that the weight of a load to be handled or that the handling requirements of a particular load might overload the crane, the foreman shall have the weight of the load confirmed (by contacting the vendor directly or by some other means).

8. A flagperson must be present at all times whenever:

a. The crane is to be working within a boom's length of an electric power line(s).

b. The operator cannot clearly see the hook or load at times.

c. The machine is being backed or moved and the operator cannot see some parts of the machine or its path of travel.

9. The flagperson shall:

a. Position himself/herself in full view of the operator and, if using hand signals, be close enough for the signals to be seen clearly. His/Her position shall allow a full view of the load and equipment at all times, yet be such that there is no danger of being injured.

b. Be qualified by experience, knowledgeable in the operation, and able to coordinate actions with the crane operator by signals. 
c. Be responsible for keeping all authorized personnel beyond the crane's operating radius.

d. Direct the load, ensuring that it never passes over the other personnel.

e. Stay in constant communication with the crane operator by either using approved hand signals, radio, sound-powered phones, or equivalent means of communication.

f. Wear high visibility orange gloves or vests.

10. This procedure provides guidance for control of lifts with cranes which are considered to be "critical" lifts and not repetitive lifts.

a. General Lifts that fall into this category are those lifts which:

i. Exceed $75 \%$ of the crane's rated capacity for the crane configuration.

ii. Require two cranes to make the lift.

iii. Are located such that the load or the crane boom could fall onto electric power lines, transformers, pipelines, or vessels or reactors containing flammable, explosive, or hazardous gases or liquids, etc.

iv. Utilize poles and derricks that have been erected for a specific lift.

b. Interpretation. Crane configuration as used in this procedure refers to variable parts of the crane such as boom length, boom angle, counterweight, outrigger's extended and set, tracks extended or retracted, and various jib attachments, headache ball, load block, lifting devices, etc.). All these items affect the gross capacity of the crane and shall be taken into consideration prior to lift.

c. Guidelines. If, in completing the permit, it is determined the lift equals or exceeds $95 \%$ of the crane configuration capacity for the greatest radius the load will achieve during pick, swing or set, the lift will not be made. If, changing the crane configuration within the manufacturing specifications, a greater gross capacity may be gained, the change shall be made. If not, a larger capacity crane shall be ordered and used.

d. Responsibilities. A "Crane Lift" Permit will be completed by the Contractor prior to making any "critical lift." After the permit has been completed by the supervisor, the required personnel will review and sign-off on the lift permit in order listed on the permit. A copy of the permit will be placed in the cab of the lift-crane and the original will be filed in the contractors on-site office.

e. Other Hazards. For any electrical or other hazard(s) involved or associated with the operations, the appropriate hazard permit(s) will also be completed prior to the lift. 
11. The use of a crane to hoist employees on a personnel platform is prohibited, except when the erection, use, and dismantling of conventional means of reaching the worksite, such as a personnel hoist, ladder, stairway, aerial lift, elevating work platform or scaffold, would be more hazardous, or is not possible because of structural design or worksite conditions. OSHA and LLNL requirements shall be strictly adhered to whenever hoisting employees by crane. 


\section{Housekeeping}

These rules apply to the NIF construction site, laydown areas, and adjacent areas of LLNL used to support NIF construction activities. Failure by a contractor/subcontractor to keep areas under their control in a safe and clean condition may cause a stop-work order to be issued by the NIF Construction Manager.

\section{Responsibilities}

NIF Construction Contractors/Subcontractors

1. All Construction Contractors/Subcontractors employees shall comply with LLNL requirements .

University Employees and non-LLNL Employees (reference Section I.A.14 for definitions)

1. All LLNL employees and non-LLNL employees (including contract labor, supplemental labor, vendors, personnel matrixed/assigned from other National Laboratories, participating guests, visitors and students) at a minimum shall comply with the LLNL Environment, Safety, and Health Program and the NIF Construction Safety Rules

\section{Exceptions}

Requests by NIF Construction Contractors/Subcontractors for exceptions/modifications to LLNL safety requirements will only be approved if equivalent safety is demonstrated and OSHA requirements are met. Approvals shall be issued in writing by the cognizant Construction Manager (or Deputy Associate Project Engineer for Construction) with concurrence from LLNL's Safety Representative for the NIF project.

\section{Housekeeping Rules for the NIF Construction Site}

a. Clean-Up. Keep your work area clean and safe at all times. Always keep yourself, the equipment you operate or are using and your place of work as clean as practicable. All contractors are responsible for clean "broom swept" areas. Dust control is the responsibility of all contractors.

b. Employee Facilities. Cooperate in keeping change rooms, toilets, first aid and drinking facilities in clean, sanitary condition.

c. Good Housekeeping. Good housekeeping will reduce confusion on the project and will result in a safer, more efficient operation. 
d. Nails \& Exposed Rebar. Protruding nails, rebar, screws or other metal in form lumber, boards, etc., must be immediately removed, bent over or capped to prevent puncture injuries.

e. Oily Rags and Wastes. Oily rags, waste or other combustible debris shall be kept in metal container provided for that purpose. Saturated oily rags must be managed as hazardous waste.

f. Removal of Debris/Garbage. When cleaning up, do not throw or drop materials from elevated levels to lower levels unless the area below is properly barricaded and adequate warnings are posted.

g. Slipping Hazards. Clean up or eliminate slipping hazards such as grease, oil, water, ice, snow or other liquids on walkways, ladders, stairways, scaffolds or other access ways or working areas.

h. Trash and Debris. Deposit trash, refuse, debris, lunch papers and other waste in the proper refuse containers.

i. Tripping Hazards. Help keep the work area, especially roadways, access ways, aisles, stairways, scaffolds and ladders clear of obstructions which may cause tripping or other accident hazards. 


\section{Material Handling and Storage}

These rules apply to the NIF construction site, laydown areas, and adjacent areas of LLNL used to support NIF construction activities. Failure by a contractor/subcontractor to keep areas under their control in a safe and clean condition may cause a stop-work order to be issued by the NIF Construction Manager.

\section{Responsibilities}

NIF Construction Contractors/Subcontractors

1. All Construction Contractors/Subcontractors employees shall comply with LLNL requirements.

University Employees and non-LLNL Employees (reference Section I.A.14 for definitions)

1. All LLNL employees and non-LLNL employees (including contract labor, supplemental labor, vendors, personnel matrixed/assigned from other National Laboratories, participating guests, visitors and students) at a minimum shall comply with the LLNL Environment, Safety, and Health Program and the NIF Construction Safety Rules

\section{Exceptions}

Requests by NIF Construction Contractors/Subcontractors for exceptions/modifications to LLNL safety requirements will only be approved if equivalent safety is demonstrated and OSHA requirements are met. Approvals shall be issued in writing by the cognizant Construction Manager (or Deputy Associate Project Engineer for Construction) with concurrence from LLNL's Safety Representative for the NIF project.

\section{Material Handling And Storage Rules For The NIF Construction Site}

a. Access. When storing materials remember to leave adequate access ways. Do not block aisles or exits.

b. Flammable/Toxic. Flammable and toxic or other harmful materials shall be stored in properly designated, well-ventilated areas. Observe and abide by "No Smoking" and other warning signs. Handling and Storage shall be in compliance with the requirements of sections 3 and 5 of Appendix A of the NIF Construction Safety Program. 
c. Heavy Loads. Do not attempt to lift heavy loads without assistance. Learn how to lift properly by bending your knees and keeping your feet together. Avoid strain by lifting with your legs and arms, not your back.

d. Life Lines. When working on material stored in silos, hoppers, tanks or similar storage areas, wear a safety harness attached to a life line and have somebody standing by in case of an emergency.

e. Non-compatible Materials. Avoid stacking non-compatible materials in the same pile. 


\section{Lead}

Due to the legacy aspects of compounds and paints that contain lead, lead shall not be used except as a shielding material unless there is no practical substitute and lead shall always be used only with the prior approval by the Laboratory. Any work involving the use of lead that is authorized by the Laboratory shall be conducted in a safe manner to prevent exposure to workers. The control of all lead work shall be based upon LLNL safety, Federal OSHA, and California OSHA requirements.

If lead work is authorized by the Laboratory, the cognizant Construction Safety Officer shall issue a Lead Work Permit in accordance with Supplement 21.20 of the LLNL Health \& Safety Manual to the individuals conducting the specific work, and a copy of the permit will be sent to ES\&H Team 2 .

\section{Responsibilities}

NIF Construction Contractors/Subcontractors

1. All contractors/subcontractors using lead must establish a lead safety program to ensure compliance with LLNL requirements of LLNL Health \& Safety Manual Supplement 21.20, Federal OSHA, and California OSHA.

2. All contractors/subcontractors are responsible to develop, document, and utilize lead safety procedures as required.

University Employees and non-LLNL Employees (reference Section I.A.14 for definitions)

1. All LLNL employees and non-LLNL employees (including contract labor, supplemental labor, vendors, personnel matrixed/assigned from other National Laboratories, participating guests, visitors and students) at a minimum shall comply with LLNL lead safety requirements.

\section{Exceptions}

Requests by NIF Construction Contractors/Subcontractors for exceptions/modifications to LLNL lead safety requirements will only be approved if equivalent safety is demonstrated and OSHA requirements are met. Approvals shall be issued in writing by the cognizant Construction Manager (or Deputy Associate Project Engineer for Construction) with concurrence from LLNL's Safety Representative for the NIF project. 


\section{Concrete and Masonry Construction}

Some concrete and masonry construction occurs on nearly all projects. All concrete and masonry construction shall be conducted in a safe manner to prevent injury to workers. The control of all concrete and masonry construction shall be based upon LLNL safety requirements, Federal OSHA, and California OSHA.

\section{Responsibilities}

NIF Construction Contractors/Subcontractors

1. All contractors/subcontractors must establish a concrete and masonry construction safety program to ensure compliance with LLNL requirements, Federal OSHA, and California OSHA.

2. All contractors/subcontractors are responsible to develop, document, and utilize concrete and masonry construction safety procedures as required.

3. All contractors/subcontractors are responsible to instruct their employees in the safety significance, purpose, and use of concrete and masonry construction safety procedures, and maintain a record thereof. Training records for contractors/subcontractors employees shall be delivered to the Construction Management for filing.

University Employees and non-LLNL Employees (reference Section I.A.14 for definitions)

1. All LLNL employees and non-LLNL employees (including contract labor, supplemental labor, vendors, personnel matrixed/assigned from other National Laboratories, participating guests, visitors and students) at a minimum shall comply with LLNL concrete and masonry construction safety requirements.

\section{Exceptions}

Requests by NIF Construction Contractors/Subcontractors for exceptions/modifications to LLNL concrete and masonry safety requirements will only be approved if equivalent safety is demonstrated and OSHA requirements are met. Approvals shall be issued in writing by the cognizant Construction Manager (or Deputy Associate Project Engineer for Construction) with concurrence from LLNL's Safety Representative for the NIF project. 


\section{Basic Rules For Concrete and Masonry Construction}

1. Fall protection shall be provided to workers when they are exposed to a fall hazard of 6 feet or more. Fall protection shall meet the requirements of Section 16 and OSHA concrete and masonry construction requirements.

2. Mason's scaffolds shall meet OSHA requirements.

3. Ladders, scaffolds, lifts, stairs, etc., shall be used to reach elevated locations. Climbing or sliding down structural steel or formwork from one level to another is not permitted.

4. Loads shall not be placed on a concrete structure unless the structure or portion of the structure is capable of supporting the loads. This must be determined by a person who is qualified in structural design.

5. All protruding reinforcing steel onto and into which a worker could fall shall be guarded to eliminate the hazard of impalement.

6. Pneumatic pipes and hoses used to pump concrete shall have all connections restrained in addition to the mechanical coupling.

7. No employee shall ride concrete buckets.

8. No employee shall work under concrete buckets while the buckets are being elevated or lowered into position. Concrete buckets shall be routed to pass over the fewest number of workers.

9. Concrete workers shall wear proper personal protective equipment. Rubber boots or rubber over-boots are required on all workers who must step in wet concrete. Rubber gloves are required on all workers who will have hand contact with wet cement or concrete. Head (hard hat) and face protection (face shield, safety glasses, or goggles) are required on workers who handle or work in close proximity to concrete being applied through a pneumatic hose. Rain gear may also be required when placing concrete.

10. Workers whose clothing, gloves, or boots, especially leather, become wet with cement or concrete shall remove the clothing, gloves, or boots and change to new clothing. Hands or skin shall be kept clean of wet or dried cement. These precautions are to prevent skin irritation and cement burns.

11. Hearing protection may be required when noise levels from concrete operations exceed accepted standards.

12. Bull float handles used where they might contact energized electric lines shall be insulated or of nonconductive material.

13. Use lockout and tag procedure, see Section 24 , when servicing or repairing any concrete or masonry equipment such as mixers, pumps, compressors, etc.

14. Formwork must be capable of supporting the intended loads without failure. Shoring that is found to be damaged or weakened shall not be used or shall be reinforced immediately. Shoring shall be inspected immediately prior to, during, and immediately after concrete placement. 
15. Formwork and shoring shall not be removed until the concrete has gained sufficient strength to support its own weight and other imposed loads.

16. Precast concrete wall units, tilt-up wall panels, and structural framing shall be adequately supported to prevent overturning and to prevent collapse.

17. No employees are allowed under precast concrete members being lifted or tilted into position except those workers required for the erection of those members. Establish a limited access zone on either side of a precast member equal to the height of the member plus four feet. Do not remove the supporting load line until the member is set in place and is secured or adequately braced to prevent tip over or collapse.

18. Establish a limited access zone whenever a masonry wall is being constructed. The limited access zone shall be equal to the height of the wall plus four feet, and shall run the entire length of the wall. No other workers besides those actively constructing the wall shall be allowed into the limited access zone.

19. Masonry wall over eight feet in height shall be adequately braced to prevent overturning and to prevent collapse.

20. Masonry saws must be guarded with at least a semicircular enclosure over the blade.

21. For safety requirements during lift slab concrete construction refer to OSHA requirements. 


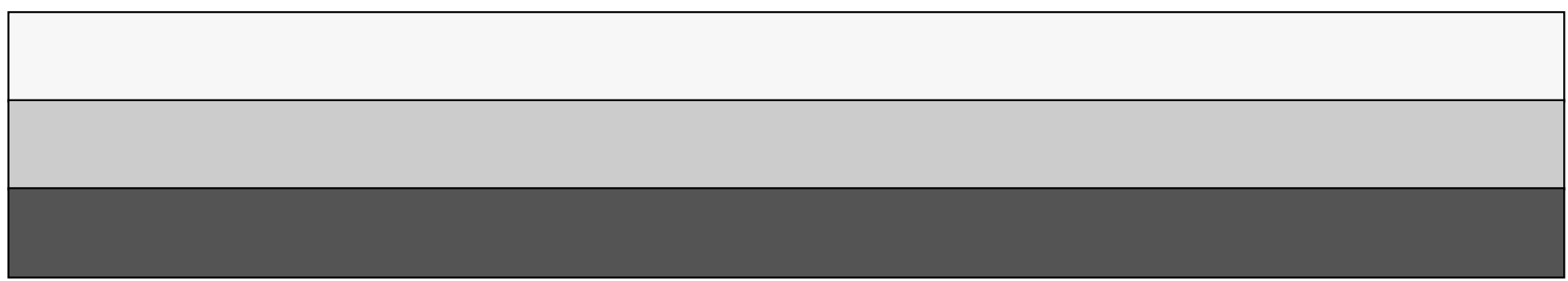

